This PDF is a selection from a published volume from the National Bureau of Economic Research

Volume Title: Innovation Policy and the Economy, Volume 6

Volume Author/Editor: Adam B. Jaffe, Josh Lerner and Scott Stern, editors

Volume Publisher: The MIT Press

Volume ISBN: 0-262-10118-1

Volume URL: http://www.nber.org/books/jaff06-1

Conference Date: April 19, 2005

Publication Date: August 2006

Title: Looking for Mr. Schumpeter: Where Are We in the Competition-Innovation Debate?

Author: Richard Gilbert

URL: http://www.nber.org/chapters/c0208 


\title{
Looking for Mr. Schumpeter: Where Are We in the Competition-Innovation Debate?
}

\author{
Richard Gilbert, University of California at Berkeley
}

\section{Executive Summary}

The effect of competition on innovation incentives has been a controversial subject in economics since Joseph Schumpeter advanced the theory that competitive markets are not necessarily the most effective organizations to promote innovation. The incentive to innovate is the difference in profit that a firm can earn if it invests in research and development compared to what it would earn if it did not invest. The concept is straightforward, yet differences in market structure, the characteristics of innovations, and the dynamics of discovery lead to seemingly endless variations in the theoretical relationship between competition and expenditures on research and development or the outputs of research and development (R\&D). This paper surveys the economic theory of innovation, focusing on market structure and its relationship to competition, the distinction between product and process innovations, and the role of exclusive and nonexclusive rights to innovation, and draws conclusions from the different models. Exclusive rights generally lead to greater innovation incentives in more competitive markets, while nonexclusive rights generally lead to the opposite conclusion, although there are important exceptions. The paper reviews the large literature on empirical studies of innovation and finds some support for the predictions of the theory.

\section{Introduction}

There is broad agreement among economists that research and development is a major source of economic growth. Although estimates differ, most studies show a high correlation between R\&D expenditures and productivity growth after accounting for investment in ordinary capital. Studies also show that the social return to investment in R\&D is higher than the private return (Griliches 1992), which suggests that policies that promote innovation can pay large dividends for society. One way to achieve these benefits is to promote industry structures that 
offer greater incentives for innovation, including policies toward mergers and laws that govern exclusionary conduct.

The objective of this paper is to review the theory and empirical evidence on the relationship between competition, market structure, and R\&D. The debate of course traces back to arguments advanced by Joseph Schumpeter $(1934,1942)$ that large firms provide a more stable platform to invest in research and development and that perfect competition is not necessarily the most efficient market structure to promote $R \& D$. The validity of the Schumpeterian view that large firms and concentrated market structures promote innovation is the subject of a voluminous theoretical and empirical literature, and the results often appear contradictory. My objective is to discern general patterns in this sea of information, a task that sometimes seems akin to unraveling the genetic code.

My focus is on the effects of competition on R\&D investment and outcomes for product and process innovations under conditions of exclusive and nonexclusive intellectual property rights. Despite the length of this survey it neglects many important aspects of competition and innovation. It does not investigate the extent to which private incentives for R\&D depart from socially optimal levels. Although the survey compares theoretical predictions for industries with exclusive and nonexclusive protection for innovation, it does not deal with information spillovers that reduce the cost of imitation. I also do not explore in this survey innovation incentives created by vertical market structures, which may affect the flow of information from consumers to producers at different levels in a supply chain, nor do I deal with topics such as the design of intellectual property rights, technology adoption, diffusion, network effects and compatibility. While these other market characteristics can have profound implications for investments in $R \& D$, the limited focus on competition provides enough complexity for our task.

A motivation for this review of the theory and evidence on the link between competition and innovation is the possibility that public policy interventions, such as antitrust and deregulation, may shape the forces for technological progress by making discrete changes in market conditions. Between 2000 and 2003 the U.S. Department of Justice and the Federal Trade Commission challenged a total of 109 mergers and mentioned innovation effects as a reason to challenge the merger in 41 cases, or in more than one out of every three merger challenges. ${ }^{1}$ These numbers understate the extent to which the U.S. antitrust agencies have 
raised innovation concerns in merger challenges, because many of the mergers that did not raise innovation concerns were in industries that performed little or no research and development. The actions of the U.S. antitrust enforcement agencies reflect a judgment that competition is a spur for innovation.

The scope for policies such as challenges to mergers is, however, limited because market structure and innovation are simultaneously determined. Sutton (1998) derives a lower bound on industry concentration under the assumption that there is free entry into an industry, entry incurs sunk costs, and all actual entrants earn non-negative profits. For example, if sunk costs are very large, profits must be similarly large to allow for non-negative profits, and therefore market concentration must be high enough to support these profits, which in turn depends on the competitive forces that operate in the industry. Sutton's lower bound approach reminds us of the importance of the simultaneous determination of market structure and $\mathrm{R} \& \mathrm{D}$. It does not strip the inquiry of all relevance because the minimum level of concentration to sustain entry could be quite low and market equilibria could exist with more concentrated markets. For example, we can ask whether the merger of two firms would increase or decrease incentives for innovation without violating Sutton's condition on the lower bound of market concentration, even if over the long run new entry may return the industry to a less concentrated level.

Section II surveys the theoretical literature on competition and R\&D. This section highlights how theoretical predictions about the relationship between competition and innovation depend on issues such as whether intellectual property rights provide exclusive protection for innovators and whether the innovation creates a new product or lowers the cost of an existing product. Section III reviews empirical studies relating firm size and competition to $\mathrm{R} \& \mathrm{D}$ in light of the predictions from the different models. The empirical studies rarely account for the many factors that the theory suggests should be significant determinants of innovative activity. Our goal is to draw conclusions from these studies to provide a better foundation for future empirical work on the market determinants of innovation. We find some support in the empirical literature for the theory, which makes predictions about the link between competition and innovation that are highly specific to characteristics of innovations and the mechanisms to protect the value created by the new technologies. As a general conclusion, there is modest support for the proposition that process innovations, which tend to 
be used internally, are more profitable for large businesses, because the benefits of process innovations are proportional to the level of production to which the innovations apply. For product innovations, there is little evidence to support the Schumpeterian view that monopoly or highly concentrated market structures promote innovation, and some evidence supporting the conclusion that innovation thrives in more competitive markets.

\section{Economic Theory of Competition and Innovation}

As a general statement, the incentive to innovate is the difference in profit that a firm can earn if it invests in R\&D compared to what it would earn if it did not invest. These incentives depend upon many factors including: the characteristics of the invention, the strength of intellectual property protection, the extent of competition before and after innovation, barriers to entry in production and R\&D, and the dynamics of R\&D. Economic theory does not offer a prediction about the effects of competition on innovation that is robust to all of these different market and technological conditions. Instead, there are many predictions, and one reason why empirical studies have not generated clear conclusions about the relationship between competition and innovation is a failure of many of these studies to account for different market and technological conditions.

The strength of intellectual property protection is an important determinant of the profit from invention because it determines the extent to which the inventor can exploit the potential of her discovery to add value. Suppose the invention is a new process that allows a manufacturer to lower its marginal production cost. The value of the new process is the increase in profit from using the new technology. For a small reduction in marginal cost, this is the amount of the cost reduction times the output for which the cost reduction applies. The value calculation is somewhat more complicated if the invention enables a large cost reduction, because the invention may allow the firm to expand its output after it adopts the new technology.

The inventor can reach a larger output if she can license the technology for use by others: If the inventor can sell or license the new technology to others, the total value that the inventor may collect is the sum of the cost reductions for all the potential adopters. If the inventor can't sell or license to others, the inventor derives no benefit from the new technology unless she can employ the new technology in her 
own operations, and in that case the value would be limited to the cost reduction for her own output. However, licensing is profitable for the inventor only if she can prevent widespread imitation without appropriate compensation.

Whether the inventor can sell or license her new technology is usually, though not necessarily, determined by whether the invention is protected by an exclusive intellectual property right, such as a patent. A patent confers the right to exclude others from making, using, or selling the invention claimed by the patent for the term of the patent grant. If the new technology is patented, the inventor can assign the patent to another firm or license one or more firms to use the new technology, perhaps in different territories or to manufacture different products. In this way, the patent allows the inventor to expand the universe of potential applications for the new technology and increase its value.

Patent protection does not guarantee that the inventor will be able to prevent competition from others, either legally by inventing-around the new technology, or illegally by infringing the patent. Several studies have shown that patents do not confer substantial protection in many industries (see, e.g., Levin et al. (1985), Cohen et al. (1989) and Hall and Ziedonis (2001)). If patent protection is weak or nonexistent, the inventor may choose to keep the new technology a secret, avoiding disclosure and thereby hoping to gain an advantage before others can imitate her discovery. In some cases a new discovery may require large complementary investments that raise barriers to entry for imitators and give the inventor at least some exclusivity. Licensing is not out of the question even if the discovery does not have the protection of a patent. Sometimes the information required to employ a new technology is so specialized that it requires extensive teaching from the inventor or another experienced user. This can be accomplished with a knowhow license. The risk to the inventor of a know-how.license is that the licensee may renege on promised royalty payments after the licensee obtains the information required to use the new technology. ${ }^{2}$ However Anton and Yao (1994) show that in the absence of patent protection an inventor may be able to discourage this type of misappropriation by threatening to license the know-how to rival firms if the licensee reneges on the terms of the agreement.

The choice to license a new discovery to others or to restrict its use to the inventor's own operations depends on the nature of patent protection and on the practicality of other means that may be available to the inventor to protect against unwanted imitators. These conditions in turn 
greatly affect the value that the inventor can extract from the new technology and the likely impacts of potential competitors on that value. Suppose that an inventor cannot obtain or design an exclusive right to a new technology because patent protection is not available or is not effective. In this case, anyone can independently discover and use the new technology. The first person to invent benefits more than others who introduce the new technology, to the extent that secrecy can give her a head start against her rivals, or if she is so dominant in the industry that she can ignore competition from rivals.

In the case of nonexclusive intellectual property rights the presence of rival firms that can independently invent and adopt the new process technology reduces the value of discovery to each potential inventor. As the number of firms that compete in research and development increases it is likely, though not necessary, that each firm's share of the total output using the new technology would fall and so would its corresponding benefit from invention. ${ }^{3}$ In this case, competition in $R \& D$ and in the market for the new technology reduces the value of innovation. With nonexclusive rights to a process technology and profit-maximizing inventors, competition can be bad for R\&D. This result is consistent with the Schumpeterian view that large firms and firms in concentrated industries have greater incentives to engage in $R \& D$ because they are better able to capture its benefits.

The strength of intellectual property protection affects incentives to invest in product innovations as well as process innovations. The analysis of these incentives is more complex for product innovations because a firm's profits before and after innovation depend on the mix of other products in its portfolio. Nonetheless, we draw some conclusions below about the profit incentives for product innovations that apply to certain types of innovations. The dynamics of the innovation process also affect incentives to invest in $R \& D$. A firm may be able to pre-empt competitors in $\mathrm{R} \& \mathrm{D}$ if a head start in the innovation process gives the firm a discrete advantage in securing an exclusive right to the innovation. If that is not the case, firms can simultaneously engage in $R \& D$, each with a reasonable expectation that its $R \& D$ expenditures will generate a significant return.

The many different predictions of theoretical models of $R \& D$ lead some to conclude that there is no coherent theory of the relationship between market structure and investment in innovation. That is not quite correct. The models have clear predictions, although they differ in important ways that can be related to market and technological 
characteristics. It is not that we don't have a model of market structure and $R \& D$, but rather that we have many models and it is important to know which model is appropriate for each market context.

\section{Incentives to Innovate with Exclusive Property Rights}

The incentive to innovate clearly depends on the nature of rights to successful innovation. If an innovator cannot exclude imitators or prevent independent discovery of similar ideas, this reduces the benefit from innovating, holding constant any spillover effects from others' innovation efforts. Here we assume that a successful inventor gains perfect and perpetual protection for her discovery. This is of course an extreme assumption and unrealistic for most market situations. Patents, for example, do not confer substantial protection in many industries, although protection can come from other means, such as secrecy and complementary investments that deter imitators. ${ }^{5}$

\section{Competition and Monopoly with Exclusive Protection for Innovation.} Under the assumption that an innovator enjoys perfect and perpetual exclusive property rights to its invention, Arrow (1962) shows that a pure monopoly that is unexposed to competition for existing and new technologies has less incentive to invest in $R \& D$ for a process invention than does a firm in a competitive industry. A firm that has a monopoly position in a market has a flow of profit that it enjoys if no innovation takes place. The monopolist can increase its profit by innovating, but it loses the profits from its old technology. On net the monopolist gains only the increment to its profits. Tirole (1997) calls this reduction in incentives due to the loss of existing profits the "replacement effect." A firm in a competitive industry has no legacy flow of profits to lose other than the normal profits for a competitive industry. If the competitive firm can capture the same benefit from innovation as the monopolist, its differential return is higher. Hence Arrow concludes that with exclusive intellectual property rights a firm in a competitive industry has a greater incentive to invest in R\&D than does a monopolist.

Arrow's model has a number of important explicit and implicit assumptions. His analysis is for a process innovation that lowers a firm's constant marginal production cost from some $c_{0}$ to $c_{1}<c_{0}$. The monopolist's incentive to invent is the profit it can earn using the new process (with resulting marginal $\operatorname{cost} c_{1}$ ) less the profit it can earn using the old process (with marginal cost $c_{0}$ ). Arrow compares this incentive 
to the incentive to invent for a firm in a competitive industry. The competitive firms supply the same homogenous product as the monopolist. Prior to invention, each competitor has a constant marginal cost $c_{0}$ and earns a profit that depends on the degree of competition among the firms in the industry. Competitive firms earn no profit using the old technology if they have constant and equal marginal costs and behave as price-taking perfect competitors. In any case, the natural forces of competition would cause a competitive firm using the old technology to earn less than a monopolist with the old technology. Arrow assumes that there is only a single successful inventor, which would be the case if the invention has perfect patent protection. The inventor's only actual or potential competition comes from the former monopolist and her profit depends on the relative $\operatorname{costs} c_{1}$ and $c_{0}$. If $c_{1}$ is sufficiently smaller than $c_{0}$, the inventor's monopoly price is less than the former monopolist's marginal cost. Arrow calls this a drastic innovation. The former monopolist has no effect on the profit that the inventor can earn using the new process technology when the invention is drastic.

For a drastic innovation, the inventor's profit is the monopoly profit with the new technology, because the old technology is obsolete. This holds whether the inventor is the monopolist or a competitive firm, provided that the inventor has a perpetual right to the new process that excludes imitators. Consequently, for a drastic invention, the (gross) payoff from invention is the same for the monopolist or a competitive firm, but the replacement effect is larger for the monopolist. The incentive to invent is the difference between the payoff from invention and the profits that are replaced by the invention. For a drastic innovation, this net payoff from invention is larger for a competitive firm than for the monopolist. ${ }^{6}$

A comparison of invention incentives is more complex if the process innovation is not drastic. For a nondrastic innovation, a competitive inventor's profit is limited by competition with the former monopolist's old technology. That is, the monopoly price corresponding to marginal cost $c_{1}$ exceeds $c_{0}$. Competition from the old technology implies that a competitive firm earns less with the new process than a pure monopolist would earn; the gross payoff from the invention is smaller for a competitive firm. However, Arrow shows that after deducting the monopolist's profit using the old technology, the net payoff from innovation is lower for the monopolist even if the process innovation is not drastic, provided that a competitor would earn no profit using the old process technology. 
Arrow's conclusions do not apply directly to product innovations, which are significant both because they account for a large fraction of total R\&D expenditures and because they include many of the breakthroughs that spur economic growth and advance consumer welfare. ${ }^{8}$ The analysis of innovation incentives is more complicated for product innovations for at least two reasons. First, even firms that act as competitive price-takers can earn positive profits when they offer differentiated products. This means that a competitive firm also faces a replacement effect from the profit that it could earn using the pre-innovation products. Second, a new product changes the ability of a monopolist to discriminate among consumers. For a process innovation, a reasonable assumption is that the new technology dominates the old technology and hence the old process technology is irrelevant to the profit that the monopolist can earn with the new process. This is not necessarily a good assumption for product innovations. A new product can allow a firm with a portfolio that includes the old product to differentiate its offerings and extract more surplus from consumers than would be possible using only the new product. ${ }^{9}$

As in the case of a process innovation, a monopolist's incentive to invest in $\mathrm{R} \& \mathrm{D}$ for a new product is the difference in the monopoly profits with and without the new product. Assuming away differences in managerial efficiency, competition ensures that a competitor's profit using the old product is no greater than a monopolist's profit using only the old product. Hence the replacement effect should be less for a competitive firm, although it is not likely to be zero when firms sell differentiated products. This implies that a competitor has a greater net incentive to invest in product innovation. However, the replacement effect is only half of the equation. A monopolist may be able earn more with the new product than a competitor could earn when it sells the new product in competition with the former monopolist. We cannot make a general conclusion that for product innovations a monopolist has a lower incentive to invent.

Greenstein and Ramey (1998) show that a monopolist can benefit more from a product innovation than a competitor. In their model all consumers prefer the new product to the old product. If the monopolist innovates, it can use the old and the new products to separate consumers according to their willingness to pay, and thereby earn more profit. They show that for a class of distributions of consumer preferences the benefit to the monopolist from introducing the new product exceeds the profit that a new competitor can earn by selling only the new product. 
The appendix provides another example of product innovation incentives. Firms are spatially differentiated; with equal prices, a consumer prefers the product sold by the firm that is closest to her location. If the spatial differentiation is not too large, the incentive for a monopoly incumbent firm to invest in a new product exceeds the incentive for a new competitor. In this example the competitor can earn a profit by selling only the old product because the products are differentiated. The competitor faces a replacement effect that dulls its incentive to innovate. The monopolist also has a replacement effect, but under some conditions the monopolist can earn more by selling both the new and the old product than a competitor can earn with only the new product.

A clear ordering of incentives for product innovation in monopoly and competitive markets is difficult to obtain even if the innovation is drastic. A product innovation is drastic if the competitor's profit is the same as if it were a monopolist with (only) the new product. Even if the innovation is drastic, this does not exclude the possibility that a monopolist could use both products to increase its profits by differentiating its offerings. We can conclude that incentives to invest in a new product are lower for the monopolist if we impose a stronger condition on the characteristics of the new product. A competitor will have a greater incentive to innovate if the new product makes the old product obsolete. This condition is stronger than the definition of a drastic invention, in the sense that any innovation that makes the old product obsolete is also drastic, but the opposite need not be the case. If the new product makes the old product obsolete for the monopolist as well as a new competitor, the competitor's gross benefit from innovation is no less than the monopolist's and it faces a smaller replacement effect. Hence the competitor's net benefit is larger.

Summarizing, we can generally conclude that competition is more likely to provide greater incentives for product innovations (as well as process innovations) if the following conditions apply:

- Competition in the old product is intense. This lowers the pre-innovation profit for a competitor and increases its incentive to invent.

- The innovation makes the old technology obsolete. Under this assumption, the monopolist's gain from innovation does not exceed the gain to a new competitor.

Pre-emptive Investment in R\&D. Joseph Schumpeter's concept of "creative destruction" assumes that monopolies are temporary and give 
way to new competition that is the result of innovation. Yet Arrow's model makes the strong assumption that the monopolist is entirely shielded from competition, even for the new product. How would innovation incentives change if we allow for competition to invent new products or processes? Gilbert and Newbery (1982) consider a simple model in which a monopolist in an existing technology and a new competitor invest in R\&D to patent a new technology. Their model assumes that the firm that invests the most wins the patent with certainty. The patent provides perfect and perpetual exclusion from competition in the new technology. Because the firm that invests the most wins the patent with certainty, the model is similar to an auction market in which the firm that bids the most wins the prize.

Gilbert and Newbery (1982) show that under some circumstances a monopolist has a greater incentive than a competitive firm to bid for the patent if the invention is nondrastic. If a competitor wins the patent, and the invention is not drastic, it competes with the former monopolist. If the competitor loses the bid for the patent, its profit is limited by the amount it can earn by competing with the old technology, which may be zero. The most that a competitor would bid for the patent is the difference between its profit with the new technology and its profit without it. If the monopolist wins the patent, it remains a monopolist and earns a corresponding monopoly profit. If it loses the bidding contest, it becomes a duopolist with the old technology and earns a duopoly profit. The monopolist's incentive to invent is the difference between the two. Under the usual assumptions, the monopolist has more to gain from winning the patent than a competitor. The monopolist gets to keep its monopoly profit if it wins, and becomes just another competitor if it loses. The monopolist's incentive to bid more for the patent than the rival can afford is the stream of monopoly profits it can retain by preempting competition. For a process innovation, the monopolist earns strictly more by preempting a rival if the innovation is not drastic, because in this case the entry of a competitor would erode the total profit that is available in the market. The difference between monopoly profits and total industry profits with the entry of a new firm is what Tirole (1997) calls the "efficiency effect." If the innovation is drastic, the new competitor can earn as much as the monopolist with the new technology and therefore has as much incentive as the monopolist to bid for the patent.

The Gilbert and Newbery model suggests that a monopolist has an incentive to preempt R\&D competition by bidding more for a patent 
than a competitor can afford to invest. By doing so, the monopolist protects its monopoly profit, and this is worth more than the competitor can earn if it wins the bid but has to compete with the former monopolist. Preemption would allow the monopoly to persist in the face of R\&D competition, however the preemption result rests on several key assumptions. These include: the firm that bids the most for the patent wins it with a high degree of certainty; the patent provides perfect protection from competition other than from the former monopolist using the old technology; there are no entry paths other than the patented technology; an entrant that wins a patent cannot bargain with the incumbent for exclusive rights to the new technology (see Salant 1984); and the monopolist faces no competition in the old technology.

To illustrate the importance of the assumption that the incumbent is a monopolist, suppose instead that there are a large number of identical incumbent firms and the innovation is a new process that allows production with a small improvement in the firm's marginal cost. If an incumbent firm succeeds in patenting the new process, the number of firms that operate in the industry is unchanged and its profit increases slightly because it has a slightly lower marginal cost. If a new competitor succeeds in winning the patent, it would earn almost as much as a successful incumbent. Vickers (1985) shows that a new competitor has a greater incentive to bid for a process patent than an incumbent in a Cournot-Nash oligopoly if the difference in marginal production cost from the new technology is sufficiently small.

In the examples discussed so far the market participants have the same cost structures before innovation occurs. Suppose firms initially have different marginal costs. Does the opportunity to innovate allow weak firms to catch up or surpass their more efficient rivals, or does innovation encourage the more efficient firms to increase the gap over their less efficient rivals? Boone (2000a) explores these incentives and shows that the incentives depend on the degree of competition among the firms. If firms compete aggressively, he shows that the most efficient firm has the highest value for a new process technology and would bid the most for it by investing in R\&D. If competition is weak, the least efficient firm has the highest value for the new process technology. ${ }^{10}$ Thus, Boone shows that R\&D to develop new process technologies will tend to sustain the position of dominant firms in industries characterized by aggressive competition, while R\&D will allow lagging firms to catch up to or leapfrog their competitors in industries characterized by weak competition. The degree of competition itself is likely to be 
endogenous. Firms are likely to compete aggressively if their costs and product qualities are not too dissimilar. Hence R\&D that changes costs and qualities will change incentives for competition, which in turn changes incentives for firms to maintain a dominant position or to leapfrog a strong competitor.

R\&D Uncertainty and Dynamics. The Gilbert-Newbery preemption result implicitly assumes that firms bid for a patent and the patent is awarded to the highest bidder. Reinganum (1983) makes the more realistic assumption that invention is uncertain; investment increases the probability that a firm will win the patent, but does not guarantee success. Her model assumes that discovery follows an exponential process: the probability that a discovery will occur before date $t$ is $F(t)=1-e^{-h t}$. The parameter $h$ is called the hazard rate, or more appropriate for this context, the success rate. It is the probability per unit time that a firm will make the discovery at time $t$ conditional on no discovery before $t$. If the success rate is constant or a constant function of R\&D investment, and if the payoffs to innovating are also constant (or appreciate at an exponential rate), then a firm's optimal investment in R\&D is independent of time, conditional on no firm making a discovery.

Reinganum (1983) shows that the monopoly preemption result in Gilbert and Newbery (1982) disappears when R\&D follows a discovery process that is exponentially distributed and the innovation is drastic, for reasons that can be traced directly to Arrow's replacement effect. If the risk is low that a competitor will innovate, a monopolist has a low incentive to invest in R\&D because it benefits only from the incremental value of the invention relative to its old technology. If the competitor's R\&D is likely to succeed, and if the invention is drastic, then the monopolist has the same incentive to invent as the inventor. In expected terms, it is profitable for the monopolist to invest less than a competitor when the invention is drastic. By extension, Reinganum argues that the monopolist has a smaller incentive to invest in $R \& D$ than a competitor even for some nondrastic innovations.

Reinganum (1985) extends the model to allow for many competitors and a sequence of innovations. Each innovation in the sequence is more valuable than its predecessor. A discovery generates a profit flow for the innovator and nothing for all other firms; that is, each discovery is a drastic innovation. The implications of this somewhat more general model parallel the results in the model with only two firms and a single innovation. A successful innovator is analogous to the incumbent in the 
duopoly model. The challengers are all the firms that did not discover the latest generation of the technology. The incumbent invests less than a challenger, as in the duopoly model, and all challengers invest at the same rate. ${ }^{11}$

These results are insightful, but it does not follow that an incumbent firm has a lower incentive to invest in $R \& D$ for all nondrastic innovations, even when the probability of discovery is exponential. Indeed the monopoly preemption result in Gilbert and Newbery (1982) can rear its head if the old technology is a sufficiently close substitute for the new technology. Closed form solutions are difficult to obtain, but it is not difficult to generate plausible numerical examples for nondrastic innovations in which the incumbent monopolist invests at more than twice the rate of a potential entrant.

We return to this dynamic theory of $R \& D$ later in the discussion of empirical studies of R\&D competition. As a theoretical matter, we note here that Arrow's result that incumbent monopolies have less to gain from innovation than competitors applies to dynamic models of R\&D when the probability of discovery is exponentially distributed and the invention is drastic. That result can change if old technologies are close substitutes for new discoveries. Furthermore, the results that follow from a model of $R \& D$ competition when the probability of discovery has an exponential distribution do not generalize to other plausible $R \& D$ technologies.

Beyond Exponential Discovery: Preemption and Leapfrog R\&D. The exponential discovery model in Reinganum (1983) is "memory-less." Each firm's probability of discovery is a function only of its current investment in R\&D.12 A firm's history of R\&D expenditures does not influence its current or future success probabilities, and there is no sense in which past expenditures can give a firm a lead in the $R \& D$ competition. Until a firm makes a discovery, the R\&D competition at each point in time looks the same and therefore optimal R\&D expenditures do not change. The exponential model is convenient and may be a reasonable approximation of $R \& D$ competition in some industries. In other circumstances one might expect that past $R \& D$ expenditures would affect current success probabilities and that each firm's optimal investment in $R \& D$ would depend on the progress that other firms have made toward discovery.

It is not unreasonable to suppose that for a given expenditure on $R \& D$ a firm has a higher probability of making discovery in any interval of 
time if it has more R\&D experience. Experience could be directly proportional to cumulative R\&D expenditures or could increase in stages. For example, early stages could correspond to intermediate discoveries or to a period of basic research, while later stages could correspond to more focused development expenditures. Fudenberg et al. (1983) and Harris and Vickers (1985a) describe patent races with the property that discovery occurs with certainty when, and only when, a firm's cumulative $\mathrm{R} \& \mathrm{D}$ exceeds some threshold. In these models, firms compete aggressively when their knowledge stocks are similar. However, if a firm falls sufficiently far behind, the leader can guarantee success and, knowing this, the follower might as well drop out of the R\&D race. The leading firm can continue to invest on the path to discovery as if the other firms did not even exist. The outcome is similar to the strategy in a sailing race. The boat that is ahead can stay ahead by blocking the wind for its competitors. It does not have to put on additional sail to increase its lead, it only has to make sure that other boats cannot overtake it. Harris and Vickers (1985a) allow for a firm to be the leader in the patent race even if it has not accumulated the largest stock of R\&D capital if other factors such as a greater patent valuation, lower discount rate, or lower cost of adding to its R\&D stock give the firm an overwhelming advantage in the R\&D competition.

A firm preempts its rivals if it has a credible strategy that guarantees success. Under some conditions, preemption can occur even if a firm has only slightly more experience than its rivals, or if firms in the R\&D competition begin with an equal footing, provided that one of the firms values the prize more than others, has a lower discount rate, or a lower cost of accumulating knowledge. The forces that determine preemption in these dynamic patent races differ from the forces in Gilbert and Newbery (1982), where a dominant firm can preempt rivals in a bidding war for a patent because it has more to gain from winning the patent. In these dynamic models, preemption occurs because one firm has a lead in a patent race that it will maintain if another firm attempts to threaten its position. Knowing this, rival firms have no hope of winning and should abandon the race. ${ }^{13}$ Furthermore, entry of additional competitors in the R\&D race should have no effect on the pace of $R \& D$ investment by the leader if the new competitors are sufficiently far behind.

If discovery is uncertain at each point in time, preemption is less likely to occur even if the probability of discovery increases with a firm's experience. A firm that is ahead cannot guarantee that it will win the patent race. Fudenberg et al. (1983), Grossman and Shapiro (1987), 
Harris and Vickers (1987) and Lippman and McCardle (1987) analyze patent races with two or more stages and exponential discovery probabilities within each stage. A firm is ahead in the technology race if it completes a stage before its rival. With stochastic discovery, a lagging firm can catch up or even leapfrog its rivals. Nonetheless, in these models of dynamic R\&D competition, a leader is more likely than a follower to win the ultimate prize, because completing a stage typically gives the firm an incentive to increase, or at least not decrease, its investment in $R \& D$.

Many of these models suggest that the dynamics of R\&D competition tend to reinforce dominance; the firm that is ahead in the technological race invests more in $R \& D$ than do followers. Even if the leader cannot preempt competition entirely, it has a higher probability of winning, and this can reinforce the knowledge gap that separates it from its rivals. Doraszelski (2003) shows that this is far from a general result. He considers a model in which the probability of success is exponential at any point in time with a success rate that depends on both current and cumulative $R \& D$ expenditures. The model is similar in appearance to Reinganum's (1981) model of a patent race with an exponential discovery probability, except that the success rate is an increasing function of the firm's cumulative R\&D expenditures. This simple twist makes the model much more difficult to solve, and most of the results rely on numerical simulations.

The simulations show that the more complicated discovery probability can support a wide range of competitive behavior in a patent race. In particular, a firm that lags a rival in cumulative R\&D experience may optimally invest more than its rival to catch up. The reason why is intuitive. Because the probability of success increases with a firm's cumulative experience, a firm that is in the lead can rest on its laurels and allow its large knowledge stock, rather than a high rate of current R\&D expenditure, to produce an innovation. This "knowledge effect" gives a follower the opportunity to catch up by spending more on R\&D. When the knowledge effect is large, the dynamics of the patent race do not reinforce dominance and there is instead an equalization effect. Firms with less cumulative R\&D experience work harder to catch up to firms with larger knowledge stocks, while firms with large knowledge stocks tend to scale back their expenditures on R\&D and coast on the value created by their past investments.

Doraszelski (2003) also shows that a firm may increase or decrease its R\&D expenditures in response to an increase in a rival's knowledge 
stock and firms may or may not compete most severely when their knowledge stocks are equal. Specific results depend on the shape of the success probability as a function of $R \& D$ experience. If the success probability is a concave function of cumulative $R \& D$, then there are diminishing returns to experience and the knowledge effect implies that a follower always invests more than the leader in R\&D. If the success probability is a convex function of cumulative $R \& D$, then $R \& D$ generates increasing returns, which gives a firm an incentive to invest and build up its knowledge capital. Even in this case, Doraszelski's simulations show that a follower has an incentive to invest to catch up to the leader once its own knowledge stock becomes sufficiently large.

Predictions of the equilibrium outcomes of patent races depend on the precise nature of the discovery technology. When experience is critical to innovation and there is little or no uncertainty in the discovery process, a firm that is ahead in the R\&D competition can maintain its lead and guarantee success. Knowing this, other firms may choose to abandon the R\&D race without a fight. Preemption is more difficult when discovery is uncertain, and in some cases a firm that is behind in the $R \& D$ race has incentives to work harder and close the gap that separates it from the current leader. Under these circumstances the dynamics of $R \& D$ competition can create incentives for $R \& D$ investments that erode the position of market leaders.

\section{RED Incentives without Exclusive Property Rights}

The theoretical results described so far assume that the innovator has an exclusive and perpetual right to exploit her invention, perhaps because the invention is rewarded with a long-lived patent that provides effective protection against imitators. We would expect the theoretical predictions to depend on this exclusivity assumption, although that is not necessarily true. A pure monopolist's incentives to invent do not depend on whether the monopolist has exclusive rights because by assumption there is no one else who can compete in either the product market or in R\&D.

Without exclusive rights, the incentives for competing firms to invest in R\&D depend on the extent of competition that would occur among firms who succeed in developing the new technology. The.incentive to invest in R\&D is low if competition post-invention would dissipate all or most of the profits. But this intuition can be misleading. Suppose that firms invest in process $R \& D$ to reduce marginal production costs from 
$c_{0}$ to $c_{1}<c_{0}$. Moreover, suppose that if two or more firms have the new technology, they would behave as perfect competitors and the resulting price would equal their marginal cost. In this case, if one firm has already developed the new technology, no rational second firm would invest in R\&D. A second inventor would earn no net revenue with the new technology and would bear the costs of R\&D. The first firm to invent therefore has effective exclusivity, because no rational second firm would invest. Of course this presumes that firms invest rationally in $R \& D$ and that they observe whether a firm has succeeded in $R \& D$ before they invest.

The incentives to invest in $R \& D$ without exclusive rights depend on the intensity of competition before and after innovation. ${ }^{14}$ Following Dasgupta and Stiglitz (1980b), consider the case of an oligopoly comprised of $N$ identical firms, each of which has pre-innovation marginal cost, $c_{0}$. The firms sell a homogenous product at price $p$. Each firm can lower its marginal cost to $c_{1}<c_{0}$ by investing in R\&D. Suppose the innovation is drastic, meaning that the profit-maximizing price for a monopolist with marginal cost $c_{1}$ is less than $c_{0}$. In this event competition will occur only among the firms that invest successfully in R\&D. Index the firms by $i=1, \ldots, N$ and suppose that $n \leq N$ firms invest in $R \& D$. Omitting the cost of R\&D, each firm makes a gross profit excluding the cost of $R \& D$ equal to

$$
\pi_{i}\left(c_{1}, n\right)=\left(p-c_{1}\right) q_{i}(p)
$$

where the price depends on the number of firms that develop the new process and the nature of the competition between them and $q_{i}(p)$ is the output of firm $i$. If $R \& D$ incurs a cost $K$, and the firms are symmetric, then the largest number of firms that can invest in $R \& D$ and earn a profit is the largest number $n$ for which

$$
\frac{1}{n}\left(p-c_{1}\right) Q(p) \geq K,
$$

where $Q(p)$ is the total output of all the firms. If a firm is maximizing profits, its price-cost margin will be inversely related to its firm-specific elasticity of demand, $\varepsilon_{f}$ This is the elasticity of the demand curve faced by the firm and is typically more elastic than the market demand curve. For example, if the firm maximizes its profits under the assumption that other firms do not change their outputs, then $\varepsilon_{f}=n \varepsilon$, where $\varepsilon$ is the elasticity of demand for the entire market and $n$ is the number of firms that successfully invent. In this case, 


$$
\frac{p-c_{1}}{p}=\frac{1}{\varepsilon_{f}}=\frac{1}{n \varepsilon}
$$

Suppose the R\&D break-even constraint (1) holds with equality. Then substituting equation (1) in (2) gives

$$
\frac{n K}{p Q}=\frac{1}{n \varepsilon} \text {. }
$$

The left-hand-side of (3) is the aggregate $R \& D$ intensity for the entire industry: the ratio of total industry $R \& D$ to total sales. The righthand-side is clearly decreasing in $n$, implying that the industry R\&D intensity is a decreasing function of the number of firms that invest in R\&D. ${ }^{15}$ Since the firms are identical, the firm-level R\&D intensity is also decreasing in the number of firms that invest in R\&D. Under the assumptions of this model a statistical cross-section of otherwise identical industries should reveal that firms in markets with fewer firms have higher R\&D intensities. A strong dose of caution is appropriate here, because even if the data were consistent with the theoretical model, we could not conclude that an increase in market concentration in any particular industry would increase R\&D intensity, because concentration is an equilibrium condition determined by characteristics of the industry and the R\&D technology.

In a social optimum, $R \& D$ investment should occur only once and the results should be made available to all of the firms in the industry. The knowledge created by the R\&D is a public good and can be used by anyone. In this example, all of the $n$ firms invest in R\&D. Competition without exclusive rights results in redundant $R \& D$ expenditures whenever two or more firms invest in R\&D for the same technology. It would be better for one firm to invest in $R \& D$ and to share the results of that knowledge with others, which would avoid $(n-1) K$ in R\&D costs.

In this example, $R \& D$ causes a discrete reduction in marginal production cost. Dasgupta and Stiglitz (1980b) obtain additional results, with some additional assumptions, when marginal cost is a declining function of investment in R\&D. If the elasticity of demand and the elasticity of marginal cost with respect to $R \& D$ are constant, they show that the level of investment in R\&D by each firm is a decreasing function of the number of competitors. Consequently, the actual level of cost reduction by each firm decreases with the number of firms that are active in $R \& D$. As in the discrete model, the total investment in $\mathrm{R} \& \mathrm{D}(n K)$ increases, 
but the actual output of innovation, as measured by the reduction in cost, is a declining function of the number of firms that actively invest in R\&D. ${ }^{16}$ Summarizing:

With nonexclusive rights to process innovations, competition can be harmful to $R \& D$ because it can reduce incentives for cost-reduction by each firm and result in redundant $R \& D$ expenditures.

In this model the incentives for innovation in an industry with $n$ firms are similar to the incentives for $n$ small monopolies to invest in cost-reducing R\&D. Larger numbers of firms correspond to smaller monopolies in this analogy. A monopolist's incentive to invest in costreducing $R \& D$ is proportional to the firm's output. Thus, it is not surprising that as the number of firms increases, the level of cost-reduction falls, precisely because the output per firm decreases. Furthermore, a monopoly in $R \& D$ can avoid redundant $R \& D$ expenditures.

$R \& D$ is unlike expenditures on conventional goods and services because $R \& D$ has properties of a public good. After discovery of a new product or process, others can use the invention at a cost that is a fraction of the cost of the original discovery. With nonexclusive intellectual property rights, firms may waste economic resources by investing in $R \& D$ to create redundant inventions. Models of $R \& D$ competition with nonexclusive intellectual property rights illustrate the hazards of using $R \& D$ expenditures as a proxy for innovative output. $R \& D$ expenditures and actual $R \& D$ outputs need not even move in the same direction when the number of firms that actively compete in R\&D in an industry increases or decreases. Exclusive intellectual property rights would encourage a firm either to develop the invention at a large scale or license the invention to others, which economizes on redundant R\&D expenditures.

\section{Managerial Incentives for Innovation}

Many of the models we have discussed so far predict a monotonic relationship between the extent of competition and innovative output. For example, in the patent race model with exponential discovery probabilities, more R\&D competitors advances the expected date at which discovery occurs (e.g. Reinganum 1985). In the Dasgupta-Stiglitz (1980b) model of cost-reducing R\&D with nonexclusive property rights, increasing the number of competitors reduces the amount of cost-reduction. The effect of competition is also monotonic in this model, although in 
the opposite direction. There is an intuitive argument that moderate levels of competition should be most effective in promoting innovation. In highly competitive markets the incentive to innovate may be low because the innovator's small scale of operations may limit its benefit from a new technology. In markets that are close to monopolies, the Arrow replacement effect should dominate. To the extent that market concentration is a reasonable proxy for the degree of competition, this would leave intermediate levels of market concentration as the most fertile environments for innovative activity. ${ }^{17}$ However, few models that rely solely on the pursuit of profit-maximization generate innovation incentives that peak at moderate levels of competition. ${ }^{18}$

A theme that resonates in the popular press is that monopolies have little incentive to innovate. For example, Steve Jobs, the CEO of Apple Computer, said "[W]hat's the point of focusing on making the product even better when the only company you can take business away from is yourself?"19 Firms have to innovate to stay ahead when others can develop new competitive products. "Only the paranoid survive"-the motto of Andrew Grove when he was the CEO of the Intel Corporation-is testimony to the vigor of dynamic competition. In markets with strong intellectual property rights, Arrow's replacement effect reinforces this view. Monopolies that are protected from innovation competition are reluctant to innovate because they merely replace one profit flow with another, while new competitors capture the entire benefit of an innovation. But with nonexclusive rights, competitive markets limit incentives to innovate because the innovator can appropriate only a fraction of the total benefits.

In the search for a more general theory of innovation incentives, and perhaps a theory in which competition motivates innovation even with nonexclusive intellectual property rights, information asymmetries between owners and managers could play an important role. Leibenstein (1966) argued that managers do not apply the effort necessary to reach the frontier of the firm's production function, and this slack is greater for managers who are not exposed to significant competition. In modern terms, managerial slack is the result of asymmetric information in a principal-agent hierarchy. The owners of firms (the principals) want managers, acting as their agents, to exert effort to run the firm in an efficient manner. This effort could include investing in and thinking creatively about new processes and products. The activity of invention requires ingenuity, hard work, and risk-taking, and often requires managers to make changes in operating procedures that are stressful for all 
and impose severe hardships on some workers. Hicks (1935) said it well when he wrote that "The best of all monopoly profits is a quiet life."

Martin (1993) develops a model in which owners offer incentives to privately informed managers to prod them to invest in cost-reducing R\&D. In other respects the model is similar to that in Dasgupta and Stiglitz (1980b) and indeed the model predictions are also similar. Investment in cost-reducing $R \& D$ is a decreasing function of the number of firms in the industry. The greater the number of competitors, the higher is the equilibrium level of the marginal cost. Private information, alone, does not change the result that competition lowers incentives for cost-reducing R\&D in the absence of exclusive intellectual property rights.

Schmidt (1997) and Aghion et al. (1999) generate stronger results about the disciplining effect of competition by allowing for the possibility of bankruptcy. Bankruptcy has punitive consequences for a firm's managers, who are at least temporarily out of a job, and they exert effort to avoid this unhappy state. In Aghion et al. (1999), adopting a new technology imposes an adjustment cost, in addition to the direct expense associated with the technology, that managers (or engineers) wish to minimize. Innovation keeps the company more efficient and reduces the likelihood of bankruptcy. All else equal, competition makes bankruptcy more likely. In their model managers innovate more in competitive markets because competition holds managers' feet to the fire. The risk of bankruptcy is low in monopolistic markets, and so is the need to innovate, hence managers of monopoly firms can enjoy the quiet life.

The model in Aghion et al. (1999) illustrates how monopoly profits can shield managers from the hard work of being innovative, but it does not lead to a robust conclusion that competition promotes innovation. As the authors note, managerial preferences could diverge from profit maximization because managers are loathe to innovate or because they are "techno-freaks" who enjoy adopting the latest new technology. If managers have an inclination to overspend on new technologies, competition would slow innovation by making bankruptcy more likely and forcing managers to be more efficient and innovate less. The effects of competition on managerial performance also depend on whether firms are active in credit markets. Managers may have to act efficiently to avoid bankruptcy if their firms are saddled with debt.

In Aghion et al. (1999), competition affects managerial payoffs solely through the risk of bankruptcy. Schmidt (1997) incorporates the prof- 
its from cost reduction in the utility function of the firm's owners and derives conditions under which competition leads to more or less effort by managers to reduce costs. In Schmidt's model, greater competition has two opposing consequences for managerial effort and innovation. By reducing each firm's demand, greater competition lowers the incentive to innovate, as in the models developed by Dasgupta and Stiglitz (1980b) and Martin (1993). Greater competition also increases the risk of bankruptcy, which encourages managers to innovate to preserve their jobs and makes it easier for the owner to induce additional effort. ${ }^{20} \mathrm{By}$ increasing the risk of bankruptcy, competition results in more innovative effort. But competition also lowers the return to a cost-reducing innovation by reducing the output of each firm. Thus, there are two effects that act in different directions. Under reasonable assumptions, the output effect should dominate if competition is sufficiently intense, which suggests that investment in cost-reducing effort should peak at some intermediate level of market concentration. Thus Schmidt's model can generate a relationship between innovation and competition that has an "inverted- $U$ " shape, as opposed to the monotonic relationship in most other models of innovation that ignore managerial incentives. Although these results are insightful, this line of inquiry would benefit from additional theoretical and empirical research. Furthermore, the results include the usual caveat that $R \& D$ investment can be redundant with nonexclusive intellectual property rights, and maximizing R\&D effort is not the same as maximizing innovative output.

\section{Other Theories and Extensions}

Most economic models of the innovation process implicitly assume that firms' proclivities to innovate are independent of the firms' identities, although there is a small economics literature that emphasizes the effects of asymmetric firm characteristics (e.g., Boone 2000a). The assumption that all firms are equal when it comes to innovation is at odds with much of the competitive strategy literature, which emphasizes differences in the abilities and desires of firms to exploit technological opportunities.

Some types of innovations are potentially disruptive to existing organizational structures within industries (see, e.g., Teece 1986). They introduce radically different technologies and are difficult to conceptualize as simple substitutes for existing processes and products, and firms react differently to the challenge of adapting to these new technologies. 
Institutional commitments to existing products or production methods can be as great a factor in the incentive to innovate as purely profitdriven considerations, such as the problem of self-induced obsolescence described by Arrow (1962) and others. Such commitments can take the form of firm-specific skills, investments in complementary assets, and a preference for established ways of doing business. Moreover, even if all firms have the same incentive to engage in research and development, it is highly unlikely that all firms are equal in the effectiveness of their innovative efforts. Firms may possess private information about R\&D opportunities or have unique assets that are related to innovation success. Variance in effectiveness also makes it difficult to posit a strong relationship between industry structure and innovation.

Henderson (1993) describes the experience of semiconductor firms that were faced with new photolithography technology for making large-scale integrated circuits. A crucial technology was the optics required to project complex circuit layouts onto semiconductor wafers. Camera companies such as Canon and Nikon had an advantage in these technologies and threatened to take business away from established integrated circuit equipment manufacturers. Although firms in both the optics and semiconductor industries had incentives to introduce the new process technologies, the winner depended in part on the ability of established companies to adapt to new technologies with which they had little experience.

The photolithography example presents a quite different take on the notion of a drastic innovation. Here, the innovation is drastic because it requires a change in the management of innovation within the firm. Henderson calls these "architectural" innovations. An innovation can be drastic in the architectural sense even if it is not drastic in the sense of creating a new monopoly price that is less than the old marginal cost.

There are many examples of architectural innovations. Electronic watches required upscale mechanical watchmakers to emphasize even more the value of their products as jewelry instead of time-keeping devices. The rise of the Internet caused Microsoft to reorganize its research efforts to put more emphasis on browsers and servers. Camera makers and film companies have had to adapt to digital photography. Some, such as Kodak, managed the transition with partial success, while Polaroid was a casualty of the digital revolution. Other market leaders, such as General Motors, DEC and IBM, have had bureaucratic problems in adapting to new technologies. Bower and Christensen (1997) 
offer several examples of once dominant firms that lost their innovative edge. These include Xerox, which lost market share to Canon and other competitors, the mechanized excavator market where Caterpillar and Deere took over from Bucyrus-Erie, the decline of Sears and the ascent of Wal-Mart, and DEC's failure to substitute PCs for its once dominant position in minicomputers. Henderson (1994) observed that some pharmaceutical companies maintained their dominance for half a century because they were able to continually remake themselves. Drug companies encourage scientists to publish. In the best companies, eminence is a criterion for promotion. They balanced science and commercial success in ways that enhanced their abilities to respond to new technological opportunities.

The history of the personal computer disk drive industry is a case study of disruptive innovation. The industry experienced a succession of significant innovations that greatly increased storage capacities and reduced costs. Christensen (1997) observed that once-dominant firms in this industry frequently lost their position as other firms leapfrogged their technological capabilities. He attributed this to an informational bias that encourages leading firms to make only incremental innovations that better serve their existing customer base, foregoing more radical innovations because they are ill-suited for their present customers. However, one does not need informational distortions to explain this type of behavior. Market-based theories, such as Reinganum's (1983) model of innovation with exponential discovery probabilities, suggest that dominant firms often have no greater incentives than new rivals to introduce drastic innovations, and their incentive may be distinctly less. Thus, it should not be surprising that new leading firms specialize in incremental innovations while major innovations come from new entrants. Moreover, in an industry with an incumbent monopolist and several potential entrants, it does not follow that the incumbent is the most likely firm to introduce a new innovation, even if the incumbent invests more than other firms. For illustration, suppose there is an incumbent and eight potential competitors, each with the same $R \& D$ technology, and the incumbent invests twice as much as any single potential competitor. The incumbent's probability of being the next successful innovator is only 20 percent. The odds are four to one that a new competitor will be the next innovator. Informational biases could explain the failure of leading firms in the disk drive industry to maintain their dominant positions, but they are clearly not the only explanation. 
Nearly all economic models that relate market structure to incentives for innovation assume that the firm's capacity for R\&D is either generated through its own expenditures or purchased in the market, for example by licensing technology from others. These models typically ignore the fact that research output depends on the human capital of the people who work for the firm, which in turn depends on their education and experience. There are well-known stories of innovative firms that were founded by scientists and engineers who owed their experience to employment in other, technologically progressive firms. An example is the sequence of innovation in semiconductor technology that began at Bell Laboratories and then moved to Shockley Semiconductor. Key executives at Shockley soon departed to form Fairchild Semiconductor, and subsequently left Fairchild to start successful new firms such as AMD, Intel, Intersil and National Semiconductor (which ultimately bought and then sold Fairchild). Studies of market structure and innovation in this industry should account for the market conditions that created the human capital that went on to found these other successful enterprises. For example, suppose that there is a highly innovative and competitive telecommunications sector, and suppose further that many of the management teams in these companies trace their employment histories to a giant such as Bell Laboratories or IBM. Is it correct to conclude that competitive markets promote innovation in this example? Perhaps a better interpretation is that competitive markets were useful only in a more limited sense to exploit innovations whose seeds were sown at Bell Labs or IBM.

Gompers, Lerner and Scharfstein (2005) is one of very few attempts to systematically examine how corporate experience has shaped innovation. The authors trace the employment histories of founders and key executives in a database of several hundred firms formed with venture capital financing from 1986 to $1999 .{ }^{21}$ They use the term "entrepreneurial spawners" to describe companies that are at the roots of the corporate histories of key executives at many new startups. Working backward through the resumes of key executives, the authors find that 70 of the startup companies in their database had management teams with prior experience at IBM, 60 at AT\&T, 55 at Sun Microsystems, and so on; 48 publicly-traded companies had employees who became key executives at more than ten different startups.

The authors consider two anecdotal explanations for entrepreneurial spawning, which they call the Xerox story and the Fairchild story. In the Xerox story, key employees leave because the bureaucracy does 
not recognize the market potential for ideas that fall outside their core business. In the Fairchild story, key employees acquire human capital and form entrepreneurial networks that facilitate new startups. They find evidence that is consistent with the Fairchild story. In particular, they find that companies, many of which were located in Silicon Valley, spawned other startups when their growth rates slowed, suggesting that expected rewards at these companies were not sufficient to retain their top executives.

This type of research is very different from studies that relate $R \& D$ to present market structures. Yet the history of human capital formation is an important component in the understanding of innovative companies and markets. While there is clearly much more that needs to be done on this important topic, the analysis in Gompers, Lerner, and Scharfstein identifies some of the building blocks for a theory of corporate experience and its effects on innovation.

\section{Innovation Diversity}

Competition in R\&D is a source of diversity in research paths that can be difficult for a single firm to duplicate. This is the flip side of the argument that monopoly can avoid the redundant expenditures on $R \& D$ that are likely to occur in competitive markets. In theory, a single firm can pursue multiple R\&D paths, but in practice it can be difficult for a single firm to maintain the diversity of inquiry that can characterize truly independent R\&D. Andrew Grove, the former CEO of Intel, described how he wanted to keep his options open by pursuing different R\&D programs for microprocessors that utilized RISC (Reduced Instruction Set Computing) and CISC (Complex Instruction Set Computing) technology. In the end, Intel abandoned RISC in favor of CISC because it was too difficult to pursue both options simultaneously (Grove 1996).

Innovation diversity is an elusive concept. Independent researchers develop capabilities and "hunches" that are difficult to replicate within a single organization. It is difficult to model the value of this type of diversity. ${ }^{22}$ It is not obvious that reducing the number of firms in an industry reduces the number of independent $R \& D$ paths. That follows if we assume that each firm takes a single R\&D path, but that need not be the case. It is common for firms to pursue several research paths. Pharmaceutical research companies test thousands of molecular combinations in search of new medicines. Semiconductor companies 
experiment with different manufacturing processes for wafer fabrication. Sah and Stiglitz (1987) consider a model in which firms can choose any number of independent $R \& D$ projects, each of which succeeds with the same probability. They show that under some conditions the equilibrium number of $R \& D$ paths is independent of the structure of the industry. Their result requires several strong assumptions. It must be the case that: (1) the value of being the only firm that has a successful project is independent of the number of firms in the market and of the distribution of unsuccessful projects in the market; (2) the value of another $R \& D$ project to a firm is zero if any other firm has a successful project; and (3) the value of another R\&D project to a firm is zero if that firm has a successful project.

In these models, a single firm can make up for the loss of diversity by increasing the number of projects undertaken at that firm. There is, however, much more to innovation diversity than counting the number of R\&D projects in the industry. Anecdotal evidence, such as Grove's recounting of Intel's experiences with RISC and CISC technologies, suggests that organizational factors limit the extent to which a firm can diversify its innovation efforts. Research programs that appear to be redundant may hide important differences, and combining such programs may risk the elimination of an alternative path of discovery. As a matter of theory, it is also possible that profit-maximizing competitive firms would choose research paths that result in excessive diversity from the perspective of economic efficiency, as firms attempt to differentiate their research activities in order to minimize competition. ${ }^{23}$

\section{The Effects of Scale}

Joseph Schumpeter praised monopoly as a source of innovation because monopoly provides a more stable platform to engage in $R \& D$ and a dominant firm can more fully exploit economies of scale in $R \& D$. R\&D investment is risky and monopoly profits can cushion the uncertain payoff of $R \& D$. Furthermore, most firms finance $R \& D$ with internally generated funds, so monopoly profits can translate into more dollars to spend on R\&D. ${ }^{24}$ Firms are likely to know more than investors about $R \& D$ prospects. Investors would be reluctant to invest in risky $R \& D$ projects if they believe that firms will use internally generated funds for projects that have high expected payoffs and will turn to the capital market only for projects that have lower payoffs. This raises the possibility that monopoly is beneficial for $R \& D$ because monopoly profits lower the cost of raising funds for R\&D. 
These observations are important, but may oversimplify the benefits of monopoly profits for R\&D investment. Internal funds are often sufficient to finance R\&D investments in many industries, even industries that are workably competitive. Firms can diversify their R\&D risks by pursuing different $R \& D$ programs and stockholders can protect themselves against risky R\&D projects by holding a portfolio of firms. Pharmaceutical research is a case in point. About 70 percent of drug $R \& D$ programs fail to pay back the cost of the $R \& D$ and the average cost of bringing a successful drug to market is enormous. The risk of failure is great, even for a large pharmaceutical R\&D firm, however investors can diversify their risk by holding a portfolio of several pharmaceutical companies.

\section{Empirical Studies of R\&D}

The previous section attempted to tease out some theoretical conclusions about the relationships between competition, firm size and innovation. It is a difficult though not entirely unrewarding task. To the extent that the literature yields any predictive results, they depend on the characteristics of innovations, the R\&D technologies, and the industries in which R\&D occurs; the details matter. ${ }^{25}$ In this section we turn to empirical studies of market structure and innovation. What does experience tell us about the most fertile environment for generating inventions and for developing their potential? How do R\&D expenditures and outcomes vary with market structures?

\section{Industries Studies of Market Structure and RED}

A very large number of empirical studies test the relationship between firm size or industry concentration and R\&D. Indeed, Aghion and Tirole (1994) call this the second most tested hypothesis in industrial organization, after the relationship between profits and firm size/concentration. There was a surge of empirical research on the Schumpeterian hypothesis that R\&D is related to firm size and competition, beginning with studies by Scherer and Mansfield in the mid-1960s. We list many of these early studies and their key observations in tables 6.1 and 6.2. The first table lists studies that relate $R \& D$ to firm size. The second does the same for market concentration, a commonly used, but highly imperfect, surrogate for competition. There is no compelling evidence from the studies listed in the first table that $R \& D$ intensity (the ratio of $R \& D$ expenditures or innovative output to sales) increases with firm size 
Table 6.1

Early statistical studies of $R \& D$ and firm size

\begin{tabular}{|c|c|c|}
\hline Author & Measures of $R \& D$ & Conclusions \\
\hline Scherer (1965) & $\begin{array}{l}\text { Patents, R\&D } \\
\text { employment }\end{array}$ & $\begin{array}{l}\text { No evidence of R\&D intensity } \\
\text { (R\&D/Sales) increasing with firm } \\
\text { size. Some evidence of lower } \\
\text { R\&D intensity for largest firms. } \\
\text { Significant inter-industry differ- } \\
\text { ences. No correlation with profits } \\
\text { or diversification. }\end{array}$ \\
\hline Mansfield (1968) & R\&D expenditures & $\begin{array}{l}\text { Some evidence of declining R\&D } \\
\text { intensity for largest firms. }\end{array}$ \\
\hline Mansfield et al. (1977) & $\begin{array}{l}\text { R\&D expenditure, } \\
\text { innovations }\end{array}$ & $\begin{array}{l}\text { No correlation between size and } \\
\text { R\&D intensity above a threshold } \\
\text { level. Some evidence that small } \\
\text { firms account for a disproportion- } \\
\text { ate share of initial inventions. }\end{array}$ \\
\hline Link (1980) & $\begin{array}{l}\text { Rate of return on } \\
\text { R\&D }\end{array}$ & $\begin{array}{l}\text { No effect of size above a moderate } \\
\text { threshold level for } 101 \text { chemical } \\
\text { firms. }\end{array}$ \\
\hline Mansfield (1981) & R\&D expenditures & $\begin{array}{l}\text { Largest firms spent disproportion- } \\
\text { ately more on basic research, but } \\
\text { not on other R\&D. }\end{array}$ \\
\hline Scherer (1983) & $\begin{array}{l}\text { R\&D expenditures, } \\
\text { patents }\end{array}$ & $\begin{array}{l}\text { R\&D/sales and patents/sales } \\
\text { roughly constant for most indus- } \\
\text { tries. }\end{array}$ \\
\hline Bound et al. (1984) & R\&D expenditures & $\begin{array}{l}\text { Considerable variation in the elas- } \\
\text { ticity of R\&D spending with respect } \\
\text { to sales across industries. }\end{array}$ \\
\hline Scott (1984) & R\&D expenditures & $\begin{array}{l}\text { No correlation between firm size } \\
\text { and R\&D intensity after controlling } \\
\text { for fixed effects. }\end{array}$ \\
\hline $\begin{array}{l}\text { Culbertson \& Mueller } \\
\quad(1985)\end{array}$ & $\begin{array}{l}\text { R\&D employment, } \\
\text { expenditures, } \\
\text { patents }\end{array}$ & $\begin{array}{l}\text { No effect of size on R\&D intensity } \\
\text { above a moderate threshold level. }\end{array}$ \\
\hline Lunn \& Martin (1986) & R\&D expenditures & $\begin{array}{l}\text { R\&D/sales increase with line of } \\
\text { business size. }\end{array}$ \\
\hline Acs \& Audretsch (1987) & $\begin{array}{l}\text { Number of } \\
\text { innovations }\end{array}$ & $\begin{array}{l}\text { Innovations / employee and innova- } \\
\text { tions/sales greater for large firms in } \\
\text { imperfectly competitive industries, } \\
\text { lower for large firms in competitive } \\
\text { industries. No significant differ- } \\
\text { ence in the quality of innovations } \\
\text { by large and small firms. }\end{array}$ \\
\hline
\end{tabular}


Table 6.2

Early statistical studies of R\&D and market concentration

\begin{tabular}{|c|c|c|}
\hline Author & Measures of R\&D & Conclusions \\
\hline Scherer (1965) & $\begin{array}{l}\text { Patents, R\&D } \\
\text { employment }\end{array}$ & $\begin{array}{l}\text { No correlation between R\&D inten- } \\
\text { sity and concentration. }\end{array}$ \\
\hline Scherer (1967) & R\&D employment & $\begin{array}{l}\text { Positive correlation with concentra- } \\
\text { tion, then falling after } \mathrm{C} 4 \text { of } 50-55 \% \\
\text { after controlling for industry effects. }\end{array}$ \\
\hline Comanor (1967) & $R \& D$ expenditures & $\begin{array}{l}\text { R\&D intensity greatest in industries } \\
\text { with moderate barriers to entry. }\end{array}$ \\
\hline $\begin{array}{l}\text { Mansfield et al. } \\
\text { (1977) }\end{array}$ & $\begin{array}{l}\text { R\&D expenditure, } \\
\text { innovations }\end{array}$ & $\begin{array}{l}\text { Some evidence of positive correlation } \\
\text { at low levels of market concentration, } \\
\text { but none above moderate levels. }\end{array}$ \\
\hline Mansfield (1981) & R\&D expenditures & $\begin{array}{l}\text { Concentrated industries spent less on } \\
\text { basic research; otherwise concentra- } \\
\text { tion had no significant effect on R\&D. }\end{array}$ \\
\hline Scott (1984) & R\&D expenditures & $\begin{array}{l}\text { No correlation between concentration } \\
\text { and } R \& D \text { after controlling for fixed } \\
\text { effects. }\end{array}$ \\
\hline Link \& Lunn (1984) & $\begin{array}{l}\text { Rate of return on } \\
\text { R\&D }\end{array}$ & $\begin{array}{l}\text { Returns to process } R \& D \text { increased } \\
\text { with concentration. Returns to prod- } \\
\text { uct } R \& D \text { independent of concentra- } \\
\text { tion. }\end{array}$ \\
\hline $\begin{array}{l}\text { Levin and Reiss } \\
\quad(1984)\end{array}$ & R\&D expenditures & $\begin{array}{l}\text { No statistically significant correlation } \\
\text { with concentration. }\end{array}$ \\
\hline $\begin{array}{l}\text { Culbertson \& Mueller } \\
\text { (1985) }\end{array}$ & $\begin{array}{l}\text { R\&D employment, } \\
\text { expenditures, patents }\end{array}$ & $\begin{array}{l}\text { Positive correlation with concentra- } \\
\text { tion in food manufacturing industries } \\
\text { up to a threshold C4 of about } 60 \% \text {. }\end{array}$ \\
\hline Levin et al. (1985) & $\begin{array}{l}\mathrm{R} \& \mathrm{D} \text { expenditures, } \\
\text { innovations }\end{array}$ & $\begin{array}{l}\text { No effect of concentration on } R \& D \\
\text { after accounting for differences in } \\
\text { appropriability. }\end{array}$ \\
\hline Angelmar (1985) & $R \& D$ expenditures & $\begin{array}{l}\text { Concentration positively related to } \\
\text { R\&D intensity in industries with } \\
\text { low barriers to imitation, negatively } \\
\text { related to R\&D in industries with } \\
\text { high barriers to imitation. }\end{array}$ \\
\hline Lunn (1986) & Patents & $\begin{array}{l}\text { Process patents in low-tech indus- } \\
\text { tries positively related to concentra- } \\
\text { tion. No effect of concentration on } \\
\text { product patents, or process patents in } \\
\text { high-tech industries. }\end{array}$ \\
\hline $\begin{array}{l}\text { Lunn \& Martin } \\
\quad(1986)\end{array}$ & R\&D expenditures & $\begin{array}{l}\text { R\&D/sales increased with market } \\
\text { share and } C 4 \text { index in low-tech } \\
\text { industries. }\end{array}$ \\
\hline
\end{tabular}


above some threshold. Kamien and Schwartz (1982), in their review of the early empirical literature, concluded that "R\&D activity, measured by either input or output intensity, appears to increase with firm size up to a point and then level off or decline. .."(p. 103). The threshold size for effective R\&D varies widely across industries (Freeman, 1982). Baldwin and Scott (1987), summarizing many studies, conclude that: "the preponderance of evidence ... indicates that economies of scale in industrial R\&D, of both the firm and the research establishment, are in most cases exhausted well below the largest firm and research establishment size examined. The studies that have found a pervasive positive relationship between size and R\&D intensity are those drawing on samples including companies of widely ranging sizes and with little or no control for industry effects. . The Schumpeterian hypothesis relating innovation to firm size appears to hold up if interpreted as a threshold one, but does not imply that giant corporations are essential for vigorous R\&D in most fields" (p. 87).

Early studies of the relationship between market concentration and $R \& D$ spending or innovative output reported in table 6.2 showed some tendency for R\&D intensity to be larger in moderately concentrated industries, however these effects typically disappeared in more refined statistical studies that controlled for industry effects. Beginning in the mid-1980s, a second wave of researchers returned to the Schumpeterian hypothesis using more sophisticated econometric techniques and improved data on technological opportunities. Using Federal Trade Commission 1974 line of business data for 437 firms, Scott (1984) found no significant relationship between market structure and R\&D intensity after controlling for effects that were specific to firms and their industries. Also using FTC line of business data, Levin et al. (1985) initially found a statistically significant "inverted- $U$ " relationship between industry concentration and both R\&D intensity and the rate of introductions of innovations. The relationship peaked at a C4 index (the share of the largest four firms in the industry) of about 0.5-0.6; this is consistent with Scherer's (1967) earlier results. The authors then included eight variables constructed from the Yale R\&D survey to measure technological opportunity and appropriability. for each firm. These included, for example, the effectiveness of appropriation mechanisms such as secrecy, lead time and ease of imitation. Inclusion of these variables dramatically lowered the significance of the concentration variables in the $R \& D$ regression, while technological opportunity and appropriability remained significant, with the 
expected signs. These econometric studies suggest that whatever relationship exists at a general economy-wide level between industry structure and $R \& D$ is masked by differences across industries in technological opportunities, demand, and the appropriability of inventions. As Baldwin and Scott (1987) note, "The most common feature of the few R\&D and innovation analyses that have sought to control for the underlying technological environment is a dramatic reduction in the observed impact of the Schumpeterian size and market power variables."

Most of the early empirical studies identified in tables 6.1 and 6.2 suffer from several of the following problems.

\section{Limited Data on Innovative Activity and Market Competition. Many} of the studies that relate market structure to innovation rely on $R \& D$ expenditures, often at highly aggregated levels. R\&D expenditure is an input to innovation. As we have seen from models of innovation with nonexclusive property rights, greater R\&D expenditures do not translate directly into greater innovative output and indeed the opposite can be true. Market environments with nonexclusive intellectual property rights may generate redundant $R \& D$ expenditures that increase industry costs with no additional benefits for innovative output.

As an alternative, several studies focus on patent counts as a measure of innovative output. Unfortunately, the correspondence between patents and useful new products or processes is also weak in many industries. Patent values are highly skewed, with most providing little or no commercial benefit, and in industries such as semiconductors, patenting is often done for defensive purposes and is not a particularly good indication of the direction of new technology.6

A complete analysis of the determinants of innovation activity would require estimates of the expected values of discoveries and data on the $R \& D$ activities of all potential innovators. Innovations often come from unexpected sources, including from firms in unrelated industries and sometimes from individual inventors. Henderson's (1993) example of innovation in photolithography is an example of one industry (optics) generating innovations for use in another industry (semiconductor fabrication). Culbertson and Mueller (1985) note that most innovation in food processing came from firms in other industries, foreign firms and individual inventors. It is exceedingly difficult to identify all of the potential sources of innovation for many new products and processes. The sources of invention are numerous, scattered and varied. 
Firms often purchase rights to innovations made by others. ${ }^{27}$ The effects of market forces can differ significantly for investment in own$R \& D$ and for purchases of innovations from others. For example, in a study of R\&D investment behavior by German firms, Czarnitzki and Kraft (2004) found that new entrants into industries invested more in R\&D than incumbents, a result that is inconsistent with preemptive innovation by incumbent firms. However, in a companion study the authors found that incumbents spent more than entrants to license technologies from others (Czarnitzki and Kraft 2005). The exclusionary rights embodied in a license and the greater certainty that a license will go to the highest bidder apparently make preemption more likely for acquiring licenses than for investing in R\&D more generally.

Another serious data problem in many of these studies is the use of market concentration as a proxy for competition. It is well understood that markets with only a few firms can be highly competitive, and competition can be weak in markets with many firms. Competition depends on the levels and industry distribution of firm costs, qualities, and brand recognition, on barriers to entry, on characteristics of demand, and on whatever animal spirits might motivate managers. Furthermore, market concentration is clearly endogenous to innovation. Successful innovation by a market leader can create a firm that competes only weakly with other firms in the industry because it has superior production technology or product quality. Successful innovation by a firm that is far from the technological frontier can create new competition by closing the cost or product quality gap relative to the market leader, even though the size structure of the industry may appear to be the same in both cases.

Failure to Distinguish Exclusive versus Nonexclusive Property Rights. The economic theory of the incentive effects of different market structures for innovation clearly demonstrates the importance of exclusive rights for innovation incentives. With exclusive rights, the theory suggests that competition promotes innovation. There are models that predict differently, such as the preemption models in Gilbert and Newbery (1982) and Fudenberg et al. (1983). However these models require particular assumptions about market structure or the dynamics of innovation competition and do not generalize to many other reasonable market settings. Empirical tests of preemption do not generally sustain the view that incumbent firms invest in ways that effectively preempt competitors, although there are exceptions such as Blundell 
et al. (1999) and Czarnitzki and Kraft (2005) for the acquisition of licenses. As noted above, the statistical significance of market concentration as a determinant of innovation often disappears when empirical studies account for the degree to which innovators can appropriate the value of their inventions using exclusive patent rights or other means.

Failure to Distinguish Product and Process Innovations. The theory demonstrates that the effects of competition on incentives to invest in innovation can differ for process and product innovations. The distinction between product and process innovation is also important because intellectual property rights are often less effective at preventing imitation for process innovations than for product innovations (Levin et al. 1987). A process innovation covers a method of production and it can be difficult for the owner of a process patent to know if a firm's production infringes the owner's patent. Consequently, trade secret is sometimes preferred to patenting as a means to protect process innovations. Trade secret protection is nonexclusive and the theory tells us that the effects of competition on innovation incentives differ significantly for exclusive and nonexclusive intellectual property rights. Even when process innovations are patented, the patent may more closely resemble a nonexclusive right due to ease of imitation.

Despite the potentially important differences in innovation incentives for product and process innovations, few of the many empirical studies of R\&D attempt to distinguish between the two. There are some exceptions. For example, Link and Lunn (1984) examined the rate of return to $R \& D$ separately for product and process innovations. They found that returns to process $R \& D$ increased with market concentration. This is consistent with the theoretical relationship between competition and R\&D in models with nonexclusive intellectual property rights (e.g., Dasgupta and Stiglitz 1980b). For R\&D directed to new products, they found that the rate of return was independent of market concentration.

Economic theory implies that for process innovations that are not licensed or sold to others, the incentive to invest in R\&D should be proportional to pre-innovation output at the business unit level. Cohen and Klepper (1996a, 1996b) develop this argument and apply the theory to FTC line of business data. Cohen and Klepper (1996a) find that business unit size explains most of the variance in process $R \& D$ expenditures and that sales at the firm level have virtually no additional explanatory power. This result is consistent with the theoretical argument that the 
value of a process innovation that is not licensed or sold to others should be proportional to the output of the activity to which it is applied. This output is related to the business unit size, not to the total size of the firm. Cohen and Klepper's (1996a) conclusion that business unit size, and not firm size, explains most of the variance in R\&D expenditures for process innovations also contradicts the Schumpeterian theory that firm size promotes $R \& D$ because the large firm is a "more stable platform" for R\&D due to factors such as reliable cash flow, economies of scale, or diversification.

The authors find additional support for the theory that incentives for process innovation are proportional to business unit size. They find that the relationship between $R \& D$ expenditure and business unit size is weaker in industries that experience high growth or where licensing of innovations is common. These factors allow even a small firm to benefit from R\&D, either by licensing the innovation to others or by applying the innovation to higher future output. Cohen and Klepper (1996b) test the relationship between firm size and the propensity of firms to patent product and process innovations. Following Scherer (1982), they assume that a patent covers a process innovation if it is employed in the same industry in which it originates, the argument being that innovations that are kept "in-house" are more likely to relate to productive efficiency rather than to new products for sales to others. They find that the fraction of patents that are classified as process innovations tends to increase with the size of the firm. This is also consistent with the theory, as larger operations allow a firm to benefit more from a process innovation.

Differences in Technological Opportunities across Industries and Time. The "second wave" of empirical research on the Schumpeterian hypothesis drove home the point that technological opportunity and appropriability are critical to incentives for $R \& D$ and can differ greatly across industries and across time. A simple example illustrates the difficulty of sorting out changes in market competition from changes in technological opportunity as a determinant of R\&D. Home dishwashers changed little in terms of functional characteristics or appearance from 1960 to about the mid-1980s. Starting in the mid-1980s, a number of new models appeared with features such as water-efficient engineering, quiet operation and sophisticated controls. Patenting in the product classification for dishwashers accelerated rapidly about this time. The number of patents awarded in this classification held steady at about 
80 per year from 1975 until about 1985, after which the number of patents awarded annually greatly increased, reaching about 300 per year in 2004. In the decade from 1975-1985, during which time the rate of patenting was relatively low and steady, there were three major suppliers of residential built-in dishwashers and a few fringe suppliers. The increase in patenting coincided with both an increase in.the number of independent suppliers and an increase in the variety of these suppliers (domestic and foreign). What can we conclude from this? Not much, because the technology changed dramatically over this time period and the entry of the European firms not only increased the number of independent dishwasher suppliers in the U.S., it also brought new ideas to the U.S. market.

Lack of Structural Models of Innovation. Few statistical studies of innovation use a structural economic model of the determinants of innovation. We expect innovation incentives to bear a nonlinear relationship to industry characteristics, and regression analyses that merely include plausible determinants of innovation are likely to generate biased estimates. Unfortunately it is difficult to "nest" different theoretical models of R\&D in ways that would allow the econometrician to reject some models as having weak explanatory effects. Empirical studies of the relationship of prices to market structure are often constructed on standard models, such as Bertrand-Nash pricing for static games with differentiated products. The economic theory of innovation competition does not establish a clear favorite model for empirical analysis. A case could be made for the replacement effect models of Arrow (1962) and Reinganum (1985) when innovations enjoy exclusive intellectual property rights, and for a model such as Dasgupta-Stiglitz (1980b) when intellectual property rights are nonexclusive, but these models are not appropriate descriptions for all market situations.

The lack of a structural model of innovation also invites estimation errors because few variables are truly exogenous determinants of innovation. ${ }^{28}$ Empirical studies do not make a clear case that market structure affects $R \& D$, but there is little doubt that $R \& D$ is a cause of market structure, and this endogeneity greatly complicates the analysis. For example, Phillips (1971) notes that the technology for early commercial aircraft largely came from exogenous sources and neither size nor market power explained the relative $R \& D$ performances of the industry's firms. However, relative success in innovation was the primary cause of the growth of some firms and the decline of 
others, and hence of growing concentration. Mansfield (1983) found that process innovations led to radical increases in minimum optimal scale in steel and cement, and less dramatic increases for other industries. Thus, R\&D caused higher concentration in these industries. In other industries, Mansfield found that product innovations were concentration decreasing.

Failure to Control for Other Confounding Factors. With the many factors that influence the opportunity and incentives for innovation, the need for "natural experiments" that enable empirical researchers to filter out the effects of unobserved covariates is particularly important. Most of the empirical studies of market structure and innovation use large cross-section or panel data sets, for which many factors vary in the population that are inadequately controlled for by the econometrician.

More recently, a third wave of researchers has descended on the question of the relationship between market structure and R\&D. Compared to earlier studies, these researchers use more extensive data, better empirical methods to control for simultaneity of market structure and R\&D, and pay somewhat more attention to the theory. Blundell, Griffith and Van Reenen (1999) test the Schumpeterian hypothesis using firmspecific data, innovation counts from the Science Policy Research Unit and patent data. The authors control for industry heterogeneity and the simultaneous determination of R\&D and market structure by using lagged variables in a long data panel. They also check their results using separate industry studies. The authors find that more concentrated industries produce fewer innovations, but within industries, the larger firms introduced more innovations and had the largest increase in market values. They argue that this provides some evidence for preemptive R\&D by dominant firms. They find no correlation between firm size and the significance of innovations and no evidence that cash flow is a significant determinant of innovation.

Their study relies on sophisticated econometric technique, but it does not entirely dispel concerns that arise from endogenous variables and industry differences. The authors do not employ direct measures of appropriability or technological opportunity and they do not distinguish product and process innovations. The authors argue that the use of lagged variables in their long panel is a theoretically valid approach to account for endogenous variables and industry differences, but this is valid only if appropriability and technological opportunity do not 
change over time. Our simple example of R\&D in the dishwasher market suggests that this may not be a reasonable assumption.

An ideal test of the effect of competition on innovation would be a natural experiment in which external and unforeseen events cause a discrete change in the extent of competition in an industry with no other consequences for other determinants of innovation, such as technological opportunity or appropriability. There are candidates in the literature, though none of them entirely remove the influence of factors other than changes in competition. Carlin, Schaffer, and Seabright (2004) examine firm-level performance following the privatization of State-owned enterprises in 24 transition countries. They find evidence of the importance of a minimum level of rivalry in both innovation and output growth. Firms innovated more after the privatization event in markets exposed to foreign competition. They also found evidence that the presence of a few rivals was more conducive to innovative performance than the presence of many competitors, suggesting an inverted$U$ relationship between innovation and competition. Unfortunately, the data in the study relating to both competition and performance are selfreported. Some firms were new private enterprises established after privatization, while others were privatized existing firms, and some remained as State-owned enterprises. These choices are likely endogenous to other market factors such as the perceived extent of competition, as are many other characteristics of the post-privatization economy, such as regulations that affect competition. Many of the firms were very small; one-half of the sampled firms had fewer than 50 employees. Furthermore, State ownership entails many factors that influence investment in R\&D in addition to a lack of market competition.

Using published accounts of about 700 U.K. manufacturing companies over the period 1972-1986, Nickell (1996) finds that an increase in market share is associated with reduced levels of firm-level productivity and that greater competition, as measured by the number of competitors or the level of rents, is associated with higher rates of productivity growth. Although the empirical approach in Nickell (1996) potentially suffers from the confounding problem that high productivity can lead to high market share, the fact that his results show a negative correlation between productivity and market share makes this reverse causality issue somewhat less of a concern.

Changes in import policies, which cause relatively rapid changes in market structure without changing technological opportunities, are plausible albeit imperfect approximations for natural experiments. 
Significant increases in competition resulting from changes in import penetration or other industry shocks have triggered the major restructuring of some industries to achieve lower manufacturing costs and to develop new and more competitive products. ${ }^{29}$ MacDonald (1994) confirmed these observations by analyzing the determinants of the rate of growth of labor productivity (output per hour of labor) in 94 industries during the period 1972 through 1987. He found that increases in import penetration had large positive impacts on labor productivity in highly concentrated industries. Using labor productivity as an indicator, albeit imperfect, of technical change, these results suggest that a sudden increase in competition had significant beneficial impacts for technical progress in markets that had been highly concentrated. However, these are not true natural experiments because imports respond to many factors that are endogenous to innovation, and it is difficult to control for changes in technological opportunities over the time frame of the study.

Aghion et al. (2004) use detailed micro-level data on UK firms from 1987-1993 along.with patent counts and measures of foreign direct entry to estimate the relationship between patenting and market competition. Their study benefits from many policy changes and interventions that changed the structure of UK industries over the sample period, such as privatization events, changes in merger policies, and the introduction of the European Union single-market program, at least some of which are removed from, if not entirely exogenous to, the entry and innovation decisions of the firms in the sample. They find that foreign direct entry had very different effects on the innovation conduct of firms, depending on the current performance of the industry in which they operate. They defined current performance by the difference between the rates of productivity growth of the industry relative to the comparable industry in the U.S., as measured by a relative U.S./UK labor productivity index at the four-digit (SIC) level. Firms in industries that were on par with productivity growth in the U.S. tended to increase innovation in response to entry, while lagging industries did not and sometimes innovated less in response to foreign entry. They argue that technologically progressive firms can "escape" the negative effects of entry by innovating. For these firms, innovation can reduce their costs or increase their product value and make them more competitive against even efficient entrants. According to their theory, lagging firms have little hope of improving their competitive situation relative to efficient entrants, and they do not waste money by attempting to innovate. Their arguments follow the 
"step-by-step" theory of innovation in Aghion et al. (2002). The data appear to provide some empirical support for the theory, although it is not entirely clear why even lagging firms cannot catch up to or even leapfrog the current best technology through their innovative efforts.

Failure to Account for "Outliers." The objective of a statistical analysis is to identify the main determinants that influence the variables of interest. Econometric models assume that there are unobserved, latent influences that are conveniently lumped into the "error term, "but these latent factors could be major determinants of innovative outcomes. When we think of innovation, we think of individuals or companies that are outliers in some sense. They exhibit flashes of brilliance, choose a different path, and push the frontiers of technological progress. We must be careful not to suppress the role of the true innovators by burying them in the econometric error term.

Early studies, such as Jewkes et al. (1969) and Schmookler (1966) emphasized the role of the individual as the source of innovation. Some of the most commercially important discoveries have come from independent inventors with little or no contact with the industry that they have revolutionized, and hence whose influences on technology would be very difficult to capture with a regression on market structure. Chester F. Carlson, the inventor of xerography, was a patent lawyer. Gillette, the inventor of the safety razor, was a traveling salesman. J. B. Dunlop was a veterinary surgeon when he invented the pneumatic tire. An undertaker invented the automatic telephone dialing system, and the inventor of the ballpoint pen was a sometimes sculptor, painter and journalist. Even with the growth in corporate patenting and the importance of scale to the development and exploitation of innovations, we should not ignore that discoveries come from creative people.

Outliers come in many varieties. The story of innovations in dishwasher technology is consistent with a vital role played by foreign manufacturers, who designed dishwashers for consumers facing constraints that differed from the typical installation in an American home. While these models may have been initially ill suited for the American consumer, they had features, such as quiet operation, that American consumers valued and that stimulated innovation by U.S. suppliers. The history of innovation in the U.S. automobile industry shares a common thread.

Notwithstanding the generally negative findings from the second wave of empirical research on the Schumpeterian hypothesis, there 
remains a lingering view that innovative output is related to market competition. Based on an international study of the sources of competitive advantage, Michael Porter concluded that " $[R]$ ivalry has a direct role in stimulating improvement and innovation..." ${ }^{30} \mathrm{He}$ concluded that "A group of domestic rivals draws attention to the industry, encouraging investments by individuals, suppliers, and institutions that improve the national environment, and creates diversity and incentives to speed the rate of innovation..." ${ }^{31}$ Porter's thesis is that firm structure and rivalry interact with the supply of industry factors of production and demand in complex ways that are conducive to technological progress. The presence of these interdependencies likely contributes to the difficulty of uncovering clear conclusions from statistical studies of the relationship between market structure and R\&D. At the same time, Porter's analysis is essentially a cross-section statistical study, and suffers from many of the data and modeling problems that affect the other studies listed in tables 6.1 and 6.2.

\section{Industry-Specific Studies}

Given the importance of technological opportunity and industryspecific factors in $R \& D$, some of the most insightful empirical studies of the interaction between competition and innovation focus on the response of a single industry, or even a single research program, to changes in market events. These studies do not meet the test of a natural experiment in which all other factors that could affect innovation are held constant, but they at least avoid some of the problems encountered in cross-sectional studies. I discuss a few such detailed studies that focus on the dynamics of R\&D.

In 1975, the Federal Trade Commission reached a consent decree with the Xerox Corporation that required Xerox to offer nonexclusive licenses at prescribed royalties for all of its patents relating to plain paper copiers (more than 5,000 in total). The FTC order generated a discrete change in the structure of the plain paper copier industry. There was a sudden entry of new competitors who previously were foreclosed from competing in this industry because they did not have access to the Xerox patent portfolio. Bresnahan (1985) reported on the consequences of the FTC consent decree. Xerox's share of all plain paper copiers in use fell from 100 percent in the early 1970 s to about 45 percent by the mid 1980s. There was a great deal of innovative activity over this time period by both Xerox and new entrants into the plain paper copier 
industry. Changes in technological opportunities in the post-consent decree time period, such as the invention of the microprocessor, make it difficult to draw a confident conclusion that the surge in innovation was a direct result of the increase in competition brought about by the consent decree. Instead, Bresnahan focuses on the direction of innovation in the post-consent decree period. Generally, Bresnahan found that firms entered market niches that were not close substitutes for their existing product lines. For example, producers of coated paper copiers (such as SCM, A.B. Dick and Royal) moved into high-speed plain paper copiers, even though they possessed marketing and distribution expertise that would have been particularly useful in the small-volume copier segment. Many of the new entrants into the low-volume copier segment were firms that had no prior experience in the copying industry (such as Savin and Ricoh). Xerox continued to offer products for all market segments.

Bresnahan (1985) concluded that ". . firms that had a choice chose to enter product segments where higher rates of inventive activity would destroy others' rents, not their own." This is consistent with innovation incentives that follow from the Arrow replacement effect. Established firms have less incentive to innovate in their own product lines, because innovation erodes their current profit flows. However, it is difficult to conclude that the experience in the post-1975 copier industry is flatly inconsistent with preemption incentives. Plain paper copiers were a drastic innovation relative to existing technologies such as coated paper copiers and photo-duplication. Plain paper copiers put these other technologies out of business. We have seen that established firms do not have differential incentives to preempt competitors when inventions are drastic, because the new technology will bring their existing profits to an end regardless of who invents. At best we can conclude that the experience in the post-consent decree plain paper copier industry is not inconsistent with Arrow's model of innovation incentives for established firms.

Cockburn and Henderson (1995) examine R\&D expenditures by pharmaceutical firms at the therapeutic program level, in this case drugs in the class of ACE inhibitors used to treat hypertension. Their data set is useful to test models such as Reinganum's (1985) patent race, or the preemption models in Fudenberg et al. (1983) and others. The authors have detailed data on $R \& D$ expenditures for products that enjoy relatively strong patent protection. The firms are investing to patent new ethical drugs, one of the few classes of products for which patents are 
a primary means to appropriate value. Their conclusions provide valuable insights for studies of dynamic investment behavior. First they note that firms do not appear to adjust the intensity of their research programs in response to changes in $R \& D$ by their competitors. This is an important result, because the ability to monitor rivals' research progress is crucial to some models of preemptive $R \& D$, such as those in Fudenberg et al. (1983). If the data revealed firms' reactions to changes in rival investments, one would expect an increase in R\&D at the program level by one firm to induce responses (either higher or lower) by rival firms. Cockburn and Henderson do not observe this behavior. However, as they explain, this could merely reflect that observed $R \& D$ programs are equilibrium responses to market conditions. They observe equilibrium $R \& D$ intensities, not $R \& D$ levels along a reaction function. When changes in equilibrium $R \& D$ intensities occur, these are responses to market shocks that affect all competitors.

A second interesting finding in their analysis is that even in the search for ethical drugs, where patent protection is key to commercial success, the competition is not "winner take all." A discovery by one firm in a therapeutic category does not cause rival firms to abandon their R\&D programs in the same category. Indeed, several of their empirical specifications find the opposite. Discoveries by one firm tend to increase R\&D spending by rival firms. They explain this by noting that discovery is often cumulative and does not foreclose new products by other firms. For example, they observe that nine different pharmaceutical firms patented ACE-inhibitor drugs in the eight years after Squibb patented the first drug in this category in 1977. There was, however, still a significant early-mover effect; in 1990 the first two innovators (Squibb and Merck) accounted for 90 percent of U.S. sales of ACE-inhibitors.

Cockburn and Henderson's analysis suggests that drug research has large positive spillovers. Discoveries (in the form of patents) by one company tend to expand the technological opportunities of other firms and stimulate R\&D spending. Although most of the theoretical patent race literature assumes that a discovery by one firm spells doom for the profits and R\&D programs of rival firms, Cockburn and Henderson instead find that for ethical drugs in this category, research had substantial positive spillovers and drug discoveries by one firm did not foreclose additional discoveries by other firms in the same therapeutic category.

Lerner (1997) focuses on technology races in the market for computer disk drives. Lerner applies statistical rigor to the question of whether 
current industry leaders are more or less likely than other firms to develop improved disk drive technologies. The $R \& D$ racing literature typically assumes that the reward to the winner of the race is a valuable patent that excluded competitors, and patents were not important as an appropriation mechanism in the disk drive industry during the period studied by Lerner (1971-1988). Nonetheless, the market had some of the qualitative features of a "winner-take-all" competition. Leading-edge disk drives commanded much higher mark-ups than did lower performance drives. Many firms exited the industry and some of the survivors earned substantial profits, although perhaps for reasons other than pure technological prowess. Although the innovation competition that Lerner studied in the disk drive industry is clearly much more complex than a simple winner-take-all market, it has some similarities, perhaps more so than the market for ACE-inhibitors in which some follow-on innovators were highly profitable.

Lerner used storage density as a proxy for the state of a firm's disk drive technology and measured innovation in three different ways. For each firm in the industry over the sample period, Lerner measured: whether the firm introduced drives with higher density than it had shipped earlier; the extent of the improvement in density; and the time between shipment of drives with improved density. According to all of these measures, the greatest amount of innovation occurred for firms whose best drives in any year had densities within 25 and 74 percent of the best drive in the industry. The firm that was the market leader was less likely to introduce a better drive, made smaller improvements if it did introduce a better drive, and took longer to introduce a better drive than did firms whose technologies lagged the market leader.

Lerner argues that these results contradict claims that a leading firm has an incentive to preempt rivals by investing more to improve its technology. That does not necessarily follow. The costs and benefits of technological improvements depend on a firm's location on the technological frontier. It should be easier for a firm to add another rung on the technological ladder if it is half way to the top than if it is already at the top. Furthermore, a firm that is far enough ahead might be able to sustain its lead for some time without investing as much as its technologically less advantaged competitors. Lerner also found that the number of competitors did not affect the rate of technological improvement for leaders or followers. This is not surprising given the large number of firms that supplied disk drives over this period. He did find that firms with greater sales and those specializing in disk drives were 
more likely to innovate, however it is difficult to disassociate firm size from past R\&D success. Lerner does not analyze whether the firm that is the technological leader in disk drives at date $t$ is more likely than other firms to be the leader at date $t+\tau$. This question is more closely related to the preemption hypothesis, but it is difficult to test because one would expect a high degree of autocorrelation in firms' technological positions.

The observed pattern of competition that has occurred in the disk drive industry is consistent with a stochastic technology race, whether or not leading firms have some preemption incentive. Lerner's data show that over the sample period, each firm that supplied disk drives faced an average of about 25 other drive manufacturers. If each firm invested the same amount in R\&D and had identical technological capabilities, the probability that any one firm would emerge as the technological leader or maintain its technological edge is only about four percent. If leading firms had an incentive to preempt their rivals due to the efficiency effect from nondrastic innovation, the probability that leaders would emerge victorious is still rather small even if they invested at a much greater rate than any one of their competitors.

\section{Concluding Remarks}

Although it is difficult to reach robust conclusions about R\&D incentives in different market structures, the theory permits some broad characterizations. The incentives to invest in R\&D increase with the profits that a firm can earn or protect by innovating and decrease with the profits that a firm can earn if it does not innovate. For process innovations that lower marginal production costs, innovation incentives are lower for a monopoly that is protected from both product and R\&D competition than for a competitive firm, provided that the innovator maintains exclusive rights to the innovation. Allowing for competition in $R \& D$ can reverse this result. With nonexclusive intellectual property rights, competition can lower incentives to invest in process $R \& D$ by reducing each firm's output and hence its return from lower costs. Incentives are more complex for new products, because profits depend on a firm's product portfolio and even competitive firms are likely to earn profits if they supply differentiated products. Nonetheless, the results for product innovations parallel the results for process innovations if the new product is sufficiently attractive to make existing products obsolete. 
Under some conditions a firm has an incentive to preempt rivals by investing more in $R \& D$ than the rivals can earn from the innovation. Preemption may occur if a firm has a monopoly profit that it can protect by acquiring an exclusive intellectual property right, or if the firm is ahead in a patent race and can monitor the $R \& D$ activities of rivals and invest to maintain its lead. Case studies of dynamic R\&D competition do not identify preemptive R\&D expenditures by incumbent firms, although it is difficult to draw this conclusion with confidence because successful preemption eliminates rivals and leaves few traces.

With nonexclusive intellectual property rights, competition can decrease the market available to each firm and lower the return from innovation. In addition, competition can result in redundant expenditures. Costs would be reduced if a single firm invested in $R \& D$ that others could share. However, competition also can reverse these results by increasing the risk that a manager may under-perform in R\&D and lose his job because his firm is not efficient enough to survive in the marketplace.

The empirical literature is generally consistent with the conclusion that R\&D expenditures increase in proportion to business unit size above some threshold value that varies across industries. For small process innovations, this is precisely what the theory predicts. The return from investment is proportion to output at the business unit level. The finding that $R \& D$ intensity is generally constant above a threshold level is generally interpreted as providing no support for structural policy intervention to increase $R \& D$. If the ratio of $R \& D$ to sales is constant across business unit sizes, neither merger nor divestiture would increase R\&D spending, assuming no change in overall output. However, even if all firms have the same R\&D intensity, a fragmented industry would have lower R\&D incentives per firm and could result in redundant and wasteful $R \& D$ expenditures. These inefficiencies might be avoided by consolidating the business units, or by merging the R\&D activities of the separate business units in an $R \& D$ joint venture.

The empirical literature does not support a conclusion that large firms promote innovation because they provide large and stable cash flows, economies of scale (above some threshold), or risk diversification. This is contrary to Schumpeter's argument that monopoly can promote innovation by providing a "more stable platform" for R\&D. At the same time, neither theory nor empirical evidence supports a strong conclusion that competition is uniformly a stimulus to innova- 
tion. There is little evidence that there is an optimal degree of competition to promote R\&D. Empirical studies that use market concentration as a proxy for competition fail to reach a robust conclusion about the relationship between market concentration and $R \& D$ when differences in industry characteristics, technological opportunities, and appropriability are taken into account. There is some evidence that competition promotes innovation when the measure of competition is an index of proximity of firms to a technological frontier, rather than a simple measure of market concentration.

We remain far from a general theory of innovation competition, although the large body of theoretical and empirical studies is beginning to yield conclusions, however meager. Cross-industry studies of market structure and R\&D are providing sharper insights by using better data, being more careful about measures of competition, and employing econometric techniques that better control for the equilibrium relationship between market structure and innovation and other confounding factors. New learning is also emerging from individual case studies that isolate specific industry factors and technological opportunities. In time we will find Mr. Schumpeter's proper place in the debate over the relationship between competition and R\&D.

\section{Endnotes}

1. These data are from press releases, annual reports, and complaints filed by the U.S. Department of Justice and the Federal Trade Commission.

2. This risk could be avoided by requiring the licensee to pay for the know-how in advance. However, such a requirement imposes a risk on the licensee, who has to pay for the new technology before knowing what it is worth.

3. This is not a necessary result because competition lowers prices and increases total output. The increase in total output can offset the reduction in the output of each firm. See Dasgupta and Stiglitz (1980b) for a derivation of the effects under certain market assumptions.

4. We show below that this conclusion can be reversed if inventors do not follow the rules of profit-maximization.

5. See Levin et al. (1985) and Cohen and Levin (1989) for surveys of how firms value patents and other mechanisms to appropriate the value of discoveries.

6. This result could change if the process innovation expanded the monopolist's ability to price discriminate (see Baldwin and Scott (1987)). We assume that is not the case.

7. Tirole (1997) provides an elegant demonstration of this result (p. 392).

8. The National Science Foundation estimated that in 1981 , about 75 percent of all industry R\&D was directed to product innovations (National Science Foundation 2004). 
9. We avoid the question of whether the private incentives for product innovation encourage firms to supply the set of products that maximize total economic surplus. It is well known that even when firms choose among existing products, the interaction of fixed product set-up costs and price competition may cause firms to supply too many or too few products from the perspective of total economic welfare. See, e.g., Dixit and Stiglitz (1977).

10. Boone $(2000 \mathrm{~b})$ develops axiomatic conditions that characterize the degree of competition in an industry.

11. Increasing the number of competitors reduces the expected time to discovery; however the effects on each firm's R\&D efforts depend on the particular formulation of fixed and flow R\&D expenses. Increasing the number of competitors increases R\&D spending per firm when R\&D is a flow cost as in Lee and Wilde (1980). It has the opposite effect when R\&D is a fixed cost (see, e.g., Loury (1979) and Dasgupta and Stiglitz (1980a)).

12. Reinganum (1981) and (1982) describe patent races with similar discovery probabilities and characterize some of the properties of the firms' optimal strategies.

13. Harris and Vickers (1985b) combine the payoff structure in the Gilbert and Newbery (1981) model with a dynamic model of R\&D competition in which the first firm to accumulate a threshold stock of knowledge wins a patent. They show that the incumbent's differentially larger incentive can deter rivals from entering the R\&D competition.

14. Sutton (1998) emphasizes this point and explores its implications for equilibrium market structures.

15. Although the number of firms $n$ that actively compete in $R \& D$ is itself an equilibrium condition, we can vary this number by adding an additional sunk cost of entry, which affects the number of firms that can satisfy the break-even condition given by equation (1).

16. As in the case of discrete investment in $R \& D$, the aggregate and per-firm $R \& D$ intensities also decline with the number of active firms. In a model of Cournot-Nash competition with nonexclusive intellectual property rights, Farrell et al. (2004) find that the total number of R\&D projects in which the industry invests has an "inverted- $U$ " shape, reaching a maximum at an intermediate level of market concentration. $R \& D$ output falls with the number of competitors, while total welfare peaks at intermediate levels of concentration due to price competition.

17. I use the terms competition and concentration interchangeably only for discussion. It is well known that competition reflects market conduct, which need not be closely related to measures of market concentration. Furthermore, as Boone (2000b) emphasizes, market concentration is an equilibrium condition that is determined by characteristics of firms, demand, and the R\&D technology.

18. The dynamic model in Aghion et al. (2002) generates an inverted-U relationship between $R \& D$ and market concentration, but the model assumes a rather special sequential structure for innovation.

19. Interview with Steve Jobs, Business Week, October 11, 2004, p. 96.

20. This assumes that managers are not indifferent between working for the firm and taking another job. If they were indifferent, that would limit the ability of the owner to induce additional effort. 
21. The total number of venture-capital financed startups in their database increased from 221 in 1986 to 804 in 1999. The number of technology startups was 144 in 1986 and 232 in 1999, peaking at 372 in 1996.

22. Sah and Stiglitz $(1986,1988)$ attempt to do so in a series of papers that explore simple models of bureaucracy.

23. See, e.g., Dasgupta and Maskin (1987) and Farrell et al. (2002).

24. Retained earnings are the source of funds for approximately 70 percent of all R\&D investment (National Science Foundation, 2004).

25. Carlton and Gertner (2002) and Katz and Shelanski (2004) reach similar conclusions in the context of antitrust policy to promote innovation.

26. There is a large literature on the value of patents. See, e.g., Pakes and Griliches (1984), Jaffe and Trajtenberg (2002), and Hall and Ziedonis (2001). Using data supplied by the Small Business Association, Acs and Audretsch (1988) report a simple correlation of 0.467 between patents and innovations.

27. Brock (1975) observed that IBM originated only seven of 23 major early innovations in computing.

28. See, e.g., Salinger's (1980) study of concentration and profits, which suggests that both concentration and profits are likely related to innovation success.

29. See, e.g., Dertouzos et al. (1989) (describing the experience of Xerox, domestic steel and chemical producers, and commercial airline manufacturers to increased competition).

30. Porter (1990), p. 143.

31. Id. at 144 .

\section{References}

Acs, Zoltan J., and David B. Audretsch. 1987. "Innovation, Market Structure and Firm Size." Review of Economics \& Statistics: $567-574$.

Acs, Zoltan J., and David B. Audretsch. 1988. "Innovation in Large and Small Firms: An Empirical Analysis." The American Economic Review 78: 678-690.

Aghion, Philippe, and Jean Tirole. 1994. "The Management of Innovation." Quarterly Journal of Economics 109: 1185-1209.

Aghion, Philippe, Nicholas Bloom, Richard Blundell, and Peter Howitt. 2002. "Competition and Innovation: An Inverted-U Relationship." National Bureau of Economic Research Working Paper no. 9269, Cambridge, MA, National Bureau of Economic Research.

Aghion, Philippe, Richard Blundell, Rachel Griffith, Peter Howitt, and Susanne Prantl. 2004. "Firm Entry, Innovation and Growth: Theory and Micro Evidence." Harvard University Working Paper. Cambridge, MA, Harvard University.

Aghion, Philippe, Mathias Dewatripont, and Patrick Rey. 1999. "Competition, Financial Discipline and Growth." The Review of Economic Studies 66: 825-852.

Angelinar, R. 1985. "Market Structure and Research Intensity in High-TechnologicalOpportunity Industries." Journal of Industrial Economics 34: 69-79. 
Anton, James J., and Dennis A. Yao. 1994. "Expropriation and Inventions: Appropriable Rents in the Absence of Property Rights," American Economic Review 84(1): 190-209.

Arrow, Kenneth J. 1962. "Economic Welfare and the Allocation of Resources to Invention." In R.R. Nelson (Ed.), The Rate and Direction of Economic Activity. N.Y., Princeton University Press.

Baldwin, William L., and John T. Scott. 1987. Market Structure and Technological Change. In Lesourne and Sonnenschein (Eds.), Fundamentals of Pure and Applied Economics. Chur, Switzerland, and London: Harwood Academic Publishers.

Blundell, Richard, Rachel Griffith, and John Van Reenen. 1999. "Market Share, Market Value and Innovation in a Panel of British Manufacturing Firms." The Review of Economic Studies 66: 529-554.

Boone, Jan. 2000a. "Intensity of Competition and the Incentive to Innovate." International Journal of Industrial Organization 19: 705-726.

Boone, Jan. 2000b. "Competitive Pressure: The Effects on Investments in Product and Process Innovation." Rand Journal of Economics 31(3): 549-569.

Bound, John, Clint Cumming, Zvi Griliches, Bronwyn H. Hall, and Adam B. Jaffe. 1984. "Who Does R\&D and Who Patents?" In Z. Griliches (Ed.), RED, Patents and Productivity. Chicago: University of Chicago Press.

Bower, Joseph L., and Clayton M. Christensen. 1997. "Disruptive Technologies: Catching the Wave." In John Seely Brown (Ed.) Seeing Differently: Insights on Innovation. Cambridge, MA: Harvard Business Review.

Bresnahan, Timothy F. 1985. "Post-Entry Competition in the Plain Paper Copier Market." The American Economic Review 75: 15-19.

Brock, Gerald W. 1975. The U.S. Computer Industry. Cambridge, MA: Ballinger.

Carlin, Wendy, Mark E. Schaffer, and Paul Seabright. 2004. "A Minimum of Rivalry: Evidence from Transition Economies on the Importance of Competition for Innovation and Growth." C.E.P.R. Discussion Papers. CEPR Discussion Paper 4343. London, England: CEPR.

Carlton, Dennis, and Robert Gertner. 2002. "Intellectual Property, Antitrust and Strategic Behavior." NBER Working Paper no. W8976. Cambridge, MA: National Bureau of Economic Research.

Christensen, Clayton M. 1997. The Innovator's Dilemma. Boston: Harvard Business School Press.

Cockburn, Ian, and Rebecca Henderson. 1995. "Racing to Invest? The Dynamics of Competition in Ethical Drug Discovery." Journal of Economics and Management Strategy 3(3): 481-519.

Cohen, Wesley M., and Richard C. Levin. 1989. "Empirical Studies of Innovation and Market Structure." In R. Schmalensee and R.D. Willig (Eds.), Handbook of Industrial Organization, vol. II. Oxford, England: Elsener Ltd.

Cohen, Wesley M., and S. Klepper. 1996a. "A Reprise of Size and R\&D." The Economic Journal 106: 925-951.

Cohen, Wesley M., and S. Klepper. 1996b. "Firm Size and the Nature of Innovation within Industries: The Case of Process and Product R\&D." Review of Economics and Statistics 78: 232-243. 
Comanor, William S. 1967. "Market Structure, Product Differentiation, and Industrial Research." Quarterly Journal of Economics 81: 639-657.

Culbertson, J.D., and W.F. Mueller. 1985. "The Influence of Market Structure on Technological Performance in the Food-Manufacturing Industries." Review of Industrial Organization 2: 40-54.

Czarnitzki, Dirk, and Kornelius Kraft. 2004. "An Empirical Test of the Asymmetric Models on Innovative Behavior: Who Invests More Into R\&D, the Incumbent or the Challenger?" Journal of Economic Behavior and Organization 54: 153-173.

Czarnitzki, Dirk, and Kornelius Kraft. 2005. "License Expenditures of Incumbents and Potential Entrants: An Empirical Analysis on German Firm Behavior." Katholieke Universiteit Leuven working paper. OR 0543. Levven, Belgium.

Dasgupta, Partha, and Eric Maskin. 1987. "The Simple Economics of Research Portfolios." The Economic Journal 97: 581-595.

Dasgupta, Partha, and Joseph Stiglitz. 1980a. "Uncertainty, Industrial Structure, and the Speed of R\&D." Bell Journal of Economics 11: 1-28.

Dasgupta, Partha, and Joseph Stiglitz. 1980b. "Industrial Structure and the Nature of Innovative Activity." Economic Journal 90: 266-293.

Dertouzos, Michael L., et al. 1989. Made in America: Regaining the Productive Edge. Cambridge, MA: MIT Press.

Dixit, Avinash, and Joseph Stiglitz. 1977. "Monopolistic Competition and Optimum Product Diversity." American Economic Review 67: 297-308.

Doraszelski, Ulrich. 2003. "An R\&D Race with Knowledge Accumulation." Rand Journal of Economics 34(1): 20-42.

Farrell, Joseph, Richard Gilbert and Michael Katz. 2003. "Market Structure, Organizational Structure and R\&D Diversity," in Richard Arnott, Bruce Greenwald, Ravi Kanbur, and Barry Nalebuff (eds.) Economics for an Imperfect World: Essays in Honor of Joseph E. Stiglitz, MIT Press.

Freeman, Chris. 1982. The Economics of Industrial Innovation. Cambridge, MA: MIT Press.

Fudenberg, Drew, Richard Gilbert, Joseph Stiglitz, and Jean Tirole. 1983. "Preemption, Leapfrogging and Competition in Patent Races." European Economic Review 22: 3-32.

Gilbert, Richard, and David Newbery. 1982. "Preemptive Patenting and the Persistence of Monopoly." American Economic Review 72(2): 514-526.

Gompers, Paul, Josh Lerner, and David Scharfstein. 2005. Entrepreneurial Spawning: Public Corporations and the Genesis of New Ventures, 1986-1999. Journal of Finance 60: 577-614.

Greenstein, Shane, and Garey Ramey. 1998. "Market Structure, Innovation and Vertical Product Differentiation." International Journal of Industrial Organization 16: 285-311.

Griliches, Zvi. 1992. "The Search for R\&D Spillovers." Scandinavian Journal of Economics 94: S29-47.

Grossman, Gene, and Carl Shapiro. 1987. "Optimal Dynamic R\&D Competition." Economic Journal 97: 372-387. 
Grove, Andrew S. 1996. Only the Paranoid Survive. New York: Doubleday.

Hall, Bronwyn, and Rose Marie Ziedonis. 2001. "The Patent Paradox Revisited: An Empirical Study of Patenting in the U.S. Semiconductor Industry, 1979-1995." Rand Journal of Economics 32: 101-28.

Harris, Chris, and John Vickers. 1985a. "Perfect Equilibrium in a Model of a Race." Review of Economic Studies 52: 193-209.

Harris, Chris, and John Vickers. 1985b. "Patent Races and the Persistence of Monopoly." Journal of Industrial Economics 33: 461-481.

Harris, Chris, and John Vickers. 1987. "Racing with Uncertainty." Review of Economic Studies 54: 1-22.

Henderson, Rebecca. 1993. "Underinvestment and Incompetence as Responses to Radical Innovation: Evidence from Photolithographic Alignment Equipment Industry." Rand Journal Economics 24: 248-270.

Henderson, Rebecca. 1994. "Managing Innovation in the Information Age, Harvard Business Review: 100-106.

Hicks, J. R. 1935. "Annual Survey of Economic Theory: The Theory of Monopoly." Econometrica 3(1): 1-20.

Jaffe, Adam B., and Manuel Trajtenberg. 2002. Patents, Citations and Innovations: $A$ Window on the Knowledge Economy. Cambridge, MA: M.I.T. Press.

Jewkes, John, David Sawyers, and Richard Stillerman. 1969. The Sources of Invention. New York: W.W. Norton.

Kamien, Morton I., and Nancy L. Schwartz. 1982. Market Structure and Innovation. Cambridge, England, NY, NY, and Melbourne, Australia: Cambridge University Press.

Katz, Michael, and Howard Shelanski. 2004. "Merger Policy and Innovation: Must Enforcement Change to Account for Technological Change?" NBER Working Paper no. W10710. Cambridge, MA: National Bureau of Economic Research.

Lee, T., and L. Wilde. 1980. "Market Structure and Innovation: A Reformulation." Quarterly Journal of Economics 194: 429-436.

Lerner, Josh. 1997. "An Empirical Exploration of a Technology Race." Rand Journal of Economics 28(2): 228-247.

Levin, Richard C., and Peter C. Reiss. 1984. "Tests of a Schumpeterian Model of R\&D and Market Structure." In Griliches, Zvi (Ed.), RED, Patents, and Productivity. Chicago: University of Chicago Press.

Levin, Richard C., Wesley M. Cohen, and David C. Mowery. 1985. "R\&D Appropriability, Opportunity, and Market Structure: New Evidence on Some Schumpeterian.Hypotheses." American Economic Review 75: 20-24.

Levin, Richard C., Alvin K. Klevorick, Richard R. Nelson, and Sidney G. Winter. 1987. "Appropriating the Returns from Industrial R\&D." Brookings Papers on Economic Activity 1987: 783-820.

Leibenstein, Harvey. 1966. "Allocative Efficiency versus X-Efficiency." American Economic Review 56 (3): 392-415. 
Link, A. N. 1980. "Firm Size and Efficient Entrepreneurial Activity: A Reformulation of Schumpeterian Hypothesis." Journal of Political Economy 88: 771-782.

Link, A. N., and J. Lunn. 1984. "Concentration and the Returns to R\&D." Review of Industrial Organization 1: 232-239.

Lippman, Steven A., and Kevin F. McCardle. 1987. "Dropout Behavior in R\&D Races with Learning." The RAND Journal of Economics 18: 287-295.

Loury, Glenn C. 1979. "Market Structure and Innovation." Quarterly Journal of Economics 93: 395-410.

Lunn, J. 1986. "An Empirical Analysis of Process and Product Patenting: A Simultaneous Equation Framework." Journal of Industrial Economics 34: 319-330.

Lunn, J., and S. Martin. 1986. "Market Structure, Firm Structure, and Research and Development." Quarterly Review of Economics and Business 26: 31-44.

MacDonald, James M. 1994. "Does Import Competition Force Efficient Production?" Review of Economics and Statistics 76(4): 721-727.

Mansfield, E. 1968. Industrial Research and Technological Innovation: An Econometric Analysis. New York: W.W. Norton \& Comany.

Mansfield, E. 1981. "Composition of R\&D Expenditures: Relationship to Size of Firm, Concentration, and Innovative Output." Review of Economics and Statistics 63: 610615.

Mansfield, E. 1983. "Technological Change and Market Structure: An Empirical Study." American Economic Review 73: 205-209.

Mansfield, E., et al. 1977. The Production and Application of New Industrial Technologies. New York: W.W. Norton \& Comany.

Martin, Stephen. 1993. "Endogenous Firm Efficiency in a Cournot Principal-Agent Model." Journal of Economic Theory 59: 445-450.

National Science Foundation. 2004. "Product versus Process Applied Research and Development, by Selected Industry." available at <http:/ / www.nsf.gov/sbe/srs/iris>.

Nickell, Stephen J. 1996. "Competition and Corporate Performance." The Journal of Political Economy 104: 724-746.

Pakes, Ariel, and Zvi Griliches. 1984. "Patents and R\&D at the Firm Level: A First Look." In Griliches, Zvi (Ed.), RED, Patents, and Productivity, Chicago: University of Chicago Press.

Porter, Michael E. 1990. The Competitive Advantage of Nations. New York: Free Press.

Phillips, Almarin. 1971. Technology and Market Structure. Lexington, MA: Heath.

Reinganum, Jennifer F. 1981. "Dynamic Games of Innovation." Journal of Economic Theory 25: $21-41$.

Reinganum, Jennifer F. 1982. "A Dynamic Game of R and D: Patent Protection and Competitive Behavior." Econometrica 50: 671-688.

Reinganum, Jennifer F. 1983. "Uncertain Innovation and the Persistence of Monopoly." American Economic Review 73: 741-748. 
Reinganum, Jennifer F. 1985. "Innovation and Industry Evolution." Quarterly Journal of Economics 100: 81-99.

Sah, Raaj Kumar, and Joseph E. Stiglitz. 1986. "The Architecture of Economic Systems: Hierarchies and Polyarchies." The American Economic Review 76: 716-727.

Sah, Raaj Kumar, and Joseph E. Stiglitz. 1987. "The Invariance of Market Innovation to the Number of Firms." The Rand Journal of Economics 18: 98-108.

Sah, Raaj Kumar, and Joseph E. Stiglitz. 1988. "Committees, Hierarchies and Polyarchies." The Economic Journal 98: 451-470.

Salant, Stephen W. 1984. "Preemptive Patenting and the Persistence of Monopoly: Comment." The American Economic Review 74(1): 247-250.

Salinger, Michael 1980. "The Concentration-Margins Relationship Revisited." Brooking Papers (Microeconomics).

Scherer, F. Michael. 1965. "Firm Size, Market Structure, Opportunity, and the Output of Patented Inventions." The American Economic Review, vol. 55, pp. 1097-1125.

Scherer, F. Michael. 1967. "Market Structure and the Employment of Scientists and Engineers." American Economic Review 57: 524-531.

Scherer, F. Michael. 1982. "Inter-Industry Technology Flows in the United States." Research Policy 11: 227-245.

Scherer, F. Michael. 1983. "The Propensity to Patent." International Journal of Industrial Organization 1: 107-128.

Schmidt, Klaus M. 1997. "Managerial Incentives and Product Market Competition." The Review of Economic Studies 64(2): 191-213.

Schmookler, J. 1966. Invention and Economic Growth. Cambridge, MA: Harvard University Press.

Schumpeter, Joseph A. 1934. The Theory of Economic Development. Cambridge, MA: Harvard University Press. (New York: Oxford University Press, 1961.) First published in German, 1912.

Schumpeter, Joseph A. 1942. Capitalism, Socialism, and Democracy. New York: Harper and Brothers. (Harper Colophon edition, 1976.)

Scott, John T. 1984. "Firm versus Industry Variability in RED Intensity." In Griliches, Zvi (Ed.), RED, Patents, and Productivity. Chicago: University of Chicago Press, 233-40.

Sutton, John. 1998. Technology and Market Structure. Cambridge, MA: MIT Press.

Teece, David J. 1986. "Profiting from Technological Innovation: Implications for Integration, Collaboration, Licensing and Public Policy." Research Policy 15: 287-88.

Tirole, Jean. 1997. The Theory of Industrial Organization. Cambridge, MA: MIT Press.

Vickers, John. 1985. "Pre-emptive Patenting, Joint Ventures, and the Persistence of Oligopoly." International Journal of Industrial Organization 3: 261-273. 


\section{Appendix. Example of a Market in Which the Incentive to Invest in R\&D Is Greater for Monopoly Than for a Competitive Firm}

A total of $N$ consumers are uniformly distributed along a line whose length we normalize to one. Each consumer desires one unit of a good. Firm $A$ is located at the left end-point of the line. If a rival Firm $B$ enters, it locates at the right end-point of the line. As this is only an example, we simplify even further and assume that both firms have zero marginal production costs. A consumer located at point $x$ incurs a disutility of $t x$ if she buys from Firm A and incurs a disutility of $t(1-x)$ if she buys from the rival. Either firm can sell a good that all consumers value at $v_{0}$ or invest in $\mathrm{R} \& \mathrm{D}$ and sell a good that all consumers value at $v_{1}>v_{0}$.

Suppose Firm A is a monopoly. If it sells a product with value $v_{\mathrm{A}}$ at price $p$, its share of the total market is $x\left(p, v_{A}\right)=\min \left[\left(v_{A}-p\right) / t, 1\right]$ and its profit is $\pi\left(v_{A}\right)=\max _{p} N p x\left(p, v_{A}\right)$. If $v_{A} \geq 2 t$, the monopoly serves the entire market and earns ${ }^{p}$

$\pi_{A}\left(v_{A}\right)=N\left(v_{A}-t\right)$.

Now suppose the rival firm enters at the opposite end of the line. Let $p_{A}$ and $v_{A}$ be the price and product choice for Firm $A$ and $p_{B}$ and $v_{B}$ for Firm $B$. Consumers located at $x<\hat{x}$ will purchase from Firm $A$ and those located at $x \geq \hat{x}$ will purchase from Firm $\mathrm{B}$, where

$$
\hat{x}=\frac{1}{2 t}\left[t+\left(v_{A}-v_{B}\right)+\left(p_{B}-p_{A}\right)\right],
$$

provided that $p_{A}+p_{B}<v_{A}+v_{B}-t$, so that all consumers make a purchase. If each firm maximizes its profit by choosing a price assuming that its price does not affect its rival's price (the Nash assumption), then there is an equilibrium with $p_{A}=t+\left(v_{A}-v_{B}\right) / 3$ and $p_{B}=t+\left(v_{B}-v_{A}\right) / 3$, provided that $v_{A}+v_{B}>3 t$. In this equilibrium, Firm $A$ earns

$$
\pi_{A}\left(v_{A}, v_{B}\right)=\frac{N}{2 t}\left[t+\frac{1}{3}\left(v_{A}-v_{B}\right)\right]^{2}
$$

and Firm B earns

$$
\pi_{B}\left(v_{B}, v_{A}\right)=\frac{N}{2 t}\left[t+\frac{1}{3}\left(v_{B}-v_{A}\right)\right]^{2} .
$$


Assume $v_{1}>v_{0}>2 t$. The monopoly incentive to invent is

$$
\Delta \Pi^{m}=\pi_{A}\left(v_{1}\right)-\pi_{A}\left(v_{0}\right)=N\left(v_{1}-v_{0}\right)
$$

and is the same as the marginal social return from the innovation.

The competitor's profit if it enters with the old technology is

$$
\pi_{B}\left(v_{0}, v_{0}\right)=\frac{N t}{2}
$$

and

$$
\pi_{B}\left(v_{1}, v_{0}\right)=\frac{N}{2 t}\left[t+\frac{1}{3}\left(v_{1}-v_{0}\right)\right]^{2}
$$

if it enters with the new technology. Monopoly yields a greater incentive to invest in R\&D than competition if

$\pi_{A}\left(v_{1}\right)-\pi_{A}\left(v_{0}\right)>\pi_{B}\left(v_{1}, v_{0}\right)-\pi_{B}\left(v_{0}, v_{0}\right)$,

or if $v_{1}-v_{0}<12 t$.

In this example, the incentive to invest in $R \& D$ is greater under monopoly unless $v_{1}-v_{0}$ is very large relative to $t$. Note that the social value of technology $v_{i}$ is $W\left(v_{i}\right)=N\left(v_{i}-t L / 2\right)$ and $\Delta W=N\left(v_{1}-v_{0}\right)=\Delta \Pi^{m}$. The monopolist earns the entire incremental social benefit from the innovation. The return to innovation for a competitor is less for two reasons. First, competition between the competitor with the new product and its rival with the old product limits the benefit from innovation. Second, unlike the case of process innovation with constant marginal costs, the competitor earns a profit even if it does not innovate because $\pi\left(v_{0}, v_{0}\right)>0$ and this lowers its incremental return to innovation. 